Article

\title{
Diversity of Endophytes in the Botryosphaeriaceae Differs on Anacardiaceae in Disturbed and Undisturbed Ecosystems in South Africa
}

\author{
Elelwani Ramabulana ${ }^{1}\left(\mathbb{D}\right.$, Ednah Kunjeku $^{1}$, Bernard Slippers ${ }^{2}$ (D) and Martin P. A. Coetzee ${ }^{2, *(D)}$ \\ 1 Department of Plant Production, School of Agriculture, University of Venda, Private Bag X5050, \\ Thohoyandou 0950, South Africa; ramabulanaelelwani@gmail.com (E.R.); kunjekuec@gmail.com (E.K.) \\ 2 DSI-NRF Centre of Excellence in Plant Health Biotechnology (CPHB), Department of Biochemistry, \\ Genetics and Microbiology, Forestry and Agricultural Biotechnology Institute (FABI), University of Pretoria, \\ Private Bag X20, Hatfield, Pretoria 0028, South Africa; bernard.slippers@fabi.up.ac.za \\ * Correspondence: martin.coetzee@fabi.up.ac.za; Tel.: +27-12-420-4826
}

Citation: Ramabulana, E.; Kunjeku, E.; Slippers, B.; Coetzee, M.P.A. Diversity of Endophytes in the Botryosphaeriaceae Differs on Anacardiaceae in Disturbed and Undisturbed Ecosystems in South Africa. Forests 2022, 13, 341 https://doi.org/10.3390/f13020341

Academic Editor: Paulo A. Zaini

Received: 21 December 2021

Accepted: 15 February 2022

Published: 18 February 2022

Publisher's Note: MDPI stays neutral with regard to jurisdictional claims in published maps and institutional affiliations.

Copyright: (C) 2022 by the authors. Licensee MDPI, Basel, Switzerland. This article is an open access article distributed under the terms and conditions of the Creative Commons Attribution (CC BY) license (https:// creativecommons.org/licenses/by/ $4.0 /)$.

\begin{abstract}
Botryosphaeriaceae represents a diverse family of fungi with a cosmopolitan distribution and a wide host range. We studied species diversity and overlap of Botryosphaeriaceae on selected tree species of Anacardiaceae in disturbed (farming or forestry) and undisturbed (isolated and/or protected) ecosystems in the Limpopo and Mpumalanga provinces, South Africa. The disturbed sites resided at Tshikundamalema and Tshipise in Limpopo and the undisturbed sites at Nwanedi and the Mapungubwe National Park in Limpopo and the Kruger National Park in Mpumalanga. Asymptomatic branches were collected from Mangifera indica, Sclerocarya birrea and Lannea schweinfurthii trees in 2017 and 2018. Eleven species were identified using a multi-gene sequencing approach, including Diplodia allocellula, Dothiorella brevicollis, Do. dulcispinae, Do. viticola, Lasiodiplodia crassispora, L. exigua, L. gonubiensis, L. mahajangana, Neofusicoccum parvum, Oblongocollomyces sp. 1 and Oblongocollomyces sp. 2. Ten of the 11 species were identified in undisturbed ecosystems (eight species being unique), while only three species were identified in disturbed ecosystems (one species being unique). Two species were generalists on trees in disturbed and undisturbed ecosystems. Lasiodiplodia mahajangana was the most dominant species as it occurred on the three tree species of Anacardiaceae. Isolates of N. parvum occurred on both S. birrea (a native species) and $M$. indica (a non-native species) that occurred adjacent to each other in disturbed ecosystems, confirming the ability of this invasive pathogen to cross-infect native and non-native hosts and its abundance in human-disturbed environments. The findings from this study confirm the lack of host specificity for most species of Botryosphaeriaceae. The results also indicate that disturbance through human activity, such as clear-cutting, selective cutting and land-use changes, negatively influences the diversity of the Botryosphaeriaceae.
\end{abstract}

Keywords: endophyte; fungal tree pathogen; tree health; invasive pathogen

\section{Introduction}

Species of Botryosphaeriaceae are capable of infecting a broad range of monocotyledonous, dicotyledonous and gymnospermous hosts [1]. Fungi in the Botryosphaeriaceae are common and known from a variety of hosts in South Africa, including commercial fruit trees [2-4], plantation trees [5,6] and native trees [7-9]. The ability of species of Botryosphaeriaceae to infect multiple hosts facilitates their spread and establishment in new areas, increasing their threat as potential pathogens of woody trees globally $[1,10,11]$. Once introduced into a new environment, these fungi can spread and infect both related and unrelated hosts $[1,9,12]$.

In South Africa, species of Botryosphaeriaceae have been found overlapping on related tree species of Anacardiaceae [13] and Myrtaceae [7,12] and unrelated hosts in the 
Cannabaceae, Celastraceae and Fabaceae [9]. Several species of Botryosphaeriaceae, including Botryosphaeria dothidea, Lasiodiplodia mahajangana, L. pseudotheobromae, L. theobromae, Neofusicoccum kwambonambiense, N. vitifusiforme, N. luteum and N. parvum have been found on both native and non-native hosts such as Eucalyptus spp. [5,6,14], Mangifera indica [13], Malus spp. [4], Pinus spp. [5], Prunus spp. [3,4], Vachellia karroo [15], Sclerocarya birrea [13], Syzygium cordatum [7] and Vitis vinifera [2].

It is likely that some prominent species that are commonly recorded on trees in agricultural and forestry ecosystems are also invaders of trees in natural stands. This is expected for species such as B. dothidea, D. sapinea, L. theobromae and N. parvum that have been reported on various hosts globally [11,16-20]. The broad distribution of these species also indicates their ability to grow under very different climatic conditions [11,20,21].

Some species, however, appear to have a narrow host range and are known from a single host or region [21]. Species that are not commonly reported in South Africa include Botryosphaeria atrovirens, Diplodia africana, D. scrobiculata, Dothiorella brevicollis, Do. capri-amissi, Do. pretoriensis, Eutiarosporella urbis-rosarum, Eu. africana, Eu. graminis, Eu. tritici, Lasiodiplodia avicenniae, L. bruguierae, L. euphorbicola and Neofusicoccum viticlavatum [21]. Their host records might be influenced by their rare occurrence and not necessarily provide a true reflection of their ability to infect other plants. Therefore, it is not clear whether the narrow host range that has been observed for some species of Botryosphaeriaceae can be attributed to host specificity or rather the sampling strategies that were followed during sample collection.

To understand the diversity of Botryosphaeriaceae in a region, these fungi must be isolated from a variety of woody plants growing across diverse ecosystems. While the Botryosphaeriaceae have been extensively studied in South Africa, they have not been widely investigated in undisturbed ecosystems. This is because most of the work on Botryosphaeriaceae is focused on commercially important trees in human-disturbed ecosystems such as plantations, orchards and cities [2,4-6]. Where studies on native tree species have been done in South Africa, they have revealed a great diversity of Botryosphaeriaceae on various native hosts such as Vachellia spp., Euphorbia ingens, Pterocarpus angolensis, S. birrea, mangrove species and S. cordatum [21].

Fungi in the Botryosphaeriaceae were previously identified on trees of Anacardiaceae in South Africa. Currently, 11 Botryosphaeriaceae species are known to occur on S. birrea [13], 10 on M. indica [13,22] and one on Searsia lancea [9]. The family Anacardiaceae includes more than 800 species worldwide [23]. Several genera in the family are economically important, including Anacardium, Pistacia, Mangifera and Sclerocarya. Anacardium occidentale and S. birrea are highly prized for their use in traditional medicine in rural parts of Africa [23-25].

In this study, we contribute to a larger body of work considering the diversity and distribution of Botryosphaeriaceae on native and non-native trees in South Africa and the role of agricultural and forestry-related disturbance in the distribution of species. Specifically, the study determined species diversity and overlap of Botryosphaeriaceae on three species, including native (Sclerocarya birrea and Lannea schweinfurthii) and non-native (Mangifera indica) species of Anacardiaceae in disturbed (agricultural and developed areas) and undisturbed (isolated and undeveloped or protected areas) ecosystems.

\section{Materials and Methods}

\subsection{Sample Sites, Tree Health Assessment and Sampling}

Asymptomatic branches (20-30 cm long and 2-5 mm wide) showing no prior damage or disease symptoms were collected from three tree hosts, namely S. birrea, $M$. indica, and, for the first time sampled in South Africa, L. schweinfurthii, in five locations that included disturbed (developed and intensively farmed) and undisturbed or low disturbance (isolated and undeveloped, and/or protected parks) sites.

The disturbed sites were Tshikundamalema (Latitude $22^{\circ} 40^{\prime} 17.87 \mathrm{~S}$, Longitude $30^{\circ} 41^{\prime} 27.29 \mathrm{E}$ ) and Tshipise (Latitude $22^{\circ} 36^{\prime} 15.59 \mathrm{~S}$, Longitude $30^{\circ} 09^{\prime} 59.08 \mathrm{E}$ ), which are 
approximately $90 \mathrm{~km}$ apart. The land is used for agricultural purposes for the cultivation of maize, groundnuts, vegetables, as well as for livestock production. Sample collections in Tshikundamalema were made from $49 \mathrm{~S}$. birrea and $54 \mathrm{M}$. indica trees that were approximately $25 \mathrm{~m}$ from each other, in Tshipise, samples were collected from $30 \mathrm{M}$. indica and $20 \mathrm{~S}$. birrea trees that were approximately $25 \mathrm{~m}$ radius from each other.

The first undisturbed or low disturbance site was Nwanedi (Latitude $22^{\circ} 32^{\prime} 02.40 \mathrm{~S}$, Longitude $30^{\circ} 40^{\prime} 12.00 \mathrm{E}$ ). Nwanedi is situated between Tshikundamalema and Tshipise. It is a remote area with little to no human activity. The area sampled had L. schweinfurthii trees only. Samples were collected from 30 randomly selected trees that were approximately $25 \mathrm{~m}$ from each other.

The second undisturbed or low disturbance site was in the Mapungubwe National Park (Latitude $22^{\circ} 13^{\prime} 19.37$ S, Longitude $29^{\circ} 20^{\prime} 50.17$ E). Samples were collected from 54 S. birrea trees at the eastern and western sides of the park. Of these, 12 trees were in a residential yard inside the park, and they were watered twice a week. Samples from these trees were recorded for comparison of fungal species occurring on S. birrea trees in the same environment, but with different moisture levels.

The third undisturbed or low disturbance site was in the Kruger National Park (Latitude $24^{\circ} 59^{\prime} 47.21 \mathrm{~S}$, Longitude $31^{\circ} 35^{\prime} 30.79 \mathrm{E}$ ). Branch samples were collected from 68 S. birrea and 99 L. schweinfurthii trees around the Skukuza research camp. While the camp itself has human activity, the surrounding area is natural and not affected by human activities. To get a good representation of the area, samples were collected from trees at 11 different sections in the east, north, south and west of Skukuza. From each section, a minimum of 10 to a maximum of 30 trees were sampled. Five sections had S. birrea and L. schweinfurthii trees growing close to each other, three sections comprised of $S$. birrea trees only and the other three sections comprised of L. schweinfurthii trees.

In addition to sampling, the trees from which we sampled were scored for general health on a scale of $0-4$; where $0=$ healthy, $1=<25 \%$ dieback branches, $2=25-50 \%$ dieback branches, $3=>50 \%$ dieback branches and $4=$ appearing to be dying or nearly dead, but still with asymptomatic shoots. Samples were collected and transported to the laboratory for fungal isolations. Data from tree health assessment was further analysed statistically using the Chi-square $\left(\chi^{2}\right)$ test to assess the goodness of fit between health status, tree species and site using SPSS v.24 [IBM, Armonk, New York, NY, USA].

\subsection{Fungal Isolations}

Samples were surface disinfected by immersing $10 \mathrm{~cm}$ of the branch in $10 \%$ hydrogen peroxide for $2 \mathrm{~min}$, followed by rinsing twice in sterile distilled water for $1 \mathrm{~min}$ each. Subsequently, 12 discs $(0.5 \mathrm{~cm})$ were cut from each branch and plated onto $2 \%$ MEA ( $2 \%$ malt extract, $1.5 \%$ agar; Biolab, Midrand, South Africa) with streptomycin to inhibit the growth of bacteria. Primary isolates were incubated at $25^{\circ} \mathrm{C}$ and checked daily for fungal growth. Pure cultures were obtained by transferring single hyphal tips from developing colonies resembling species of Botryosphaeriaceae onto clean 2\% MEA.

Isolates were grouped based on culture morphology and colour characteristics using the colour chart by Rayner [26]. Isolates were grouped into 11 cultural morphogroups, from which 2-10 isolates representing the different tree species and sites were selected. In total, 78 isolates were selected for preliminary ITS identification. Of these, 52 isolates were obtained from $S$. birrea trees sampled at Tshikundamalema, Tshipise, Mapungubwe and Kruger National Park, 16 from L. schweinfurthii trees at Nwanedi and Kruger National Park and 10 from $M$. indica trees at Tshipise and Tshikundamalema. Isolates used in this study (Table 1) are maintained in the culture collection (CMW) of the Forestry and Agricultural Biotechnology Institute (FABI), University of Pretoria, South Africa. 
Table 1. Representative fungal isolates obtained from tree species of Anacardiaceae in this study and used in the phylogenetic analyses.

\begin{tabular}{|c|c|c|c|c|c|c|c|}
\hline \multirow[t]{2}{*}{ Isolate No. } & \multirow[t]{2}{*}{ Identity } & \multirow[t]{2}{*}{ Host } & \multirow[t]{2}{*}{ Location } & \multicolumn{4}{|c|}{ GenBank } \\
\hline & & & & ITS & tef1- $\alpha$ & $\beta-t u b$ & $r p b 2$ \\
\hline CMW54349 & Diplodia allocellula & Lannea schweinfurthii & Nwanedi & OL441853 & OL441909 & OL441965 & OM585579 \\
\hline CMW54351 & D. allocellula & Sclerocarya birrea & Kruger & OL441855 & OL441911 & OL441967 & OM585581 \\
\hline CMW54353 & D. allocellula & Lannea schweinfurthii & Kruger & OL441857 & OL441913 & OL441969 & OM585583 \\
\hline CMW57629 & Dothiorella brevicollis & Lannea schweinfurthii & Nwanedi & OL441858 & OL441914 & OL441970 & - \\
\hline CMW57630 & Do. brevicollis & Sclerocarya birrea & Mapungubwe & OL441859 & OL441915 & OL441971 & - \\
\hline CMW57462 & Do. dulcispinae & Sclerocarya birrea & Kruger & OL441861 & OL441917 & OL441973 & - \\
\hline CMW57466 & Do. dulcispinae & Sclerocarya birrea & Mapungubwe & OL441862 & OL441918 & OL441974 & - \\
\hline CMW57463 & Do. viticola & Sclerocarya birrea & Mapungubwe & OL441863 & OL441919 & OL441975 & - \\
\hline CMW57464 & Do. viticola & Sclerocarya birrea & Mapungubwe & OL441864 & OL441920 & OL441976 & - \\
\hline CMW54318 & Lasiodiplodia crassispora & Lannea schweinfurthii & Kruger & OL441866 & OL441922 & OL441978 & OL442021 \\
\hline CMW54319 & L. crassispora & Sclerocarya birrea & Tshikundamalema & OL441867 & OL441923 & OL441979 & OL442022 \\
\hline CMW54320 & L. crassispora & Sclerocarya birrea & Mapungubwe & OL441868 & OL441924 & OL441980 & OL442023 \\
\hline CMW57579 & L. crassispora & Sclerocarya birrea & Kruger & OL441870 & OL441926 & OL441982 & OL442025 \\
\hline CMW54314 & L. gonubiensis & Sclerocarya birrea & Kruger & OL441873 & OL441929 & OL441985 & OL442028 \\
\hline CMW54315 & L. gonubiensis & Sclerocarya birrea & Kruger & OL441874 & OL441930 & OL441986 & OL442029 \\
\hline
\end{tabular}


Table 1. Cont.

\begin{tabular}{|c|c|c|c|c|c|c|c|}
\hline \multirow[t]{2}{*}{ Isolate No. } & \multirow[t]{2}{*}{ Identity } & \multirow[t]{2}{*}{ Host } & \multirow[t]{2}{*}{ Location } & \multicolumn{4}{|c|}{ GenBank } \\
\hline & & & & ITS & tef1- $\alpha$ & $\beta-t u b$ & $r p b 2$ \\
\hline CMW54312 & L. exigua & Sclerocarya birrea & Mapungubwe & OL441875 & OL441931 & OL441987 & OL442030 \\
\hline CMW54313 & L. exigua & Sclerocarya birrea & Mapungubwe & OL441876 & OL441932 & OL441988 & OL442031 \\
\hline CMW54326 & L. mahajangana & Mangifera indica & Tshikundamalema & OL441877 & OL441933 & OL441989 & OL442032 \\
\hline CMW54329 & L. mahajangana & Lannea schweinfurthii & Nwanedi & OL441878 & OL441934 & OL441990 & OL442033 \\
\hline CMW54331 & L. mahajangana & Sclerocarya birrea & Mapungubwe & OL441880 & OL441936 & OL441992 & OL442035 \\
\hline CMW54357 & Neofusicoccum parvum & Sclerocarya birrea & Tshipise & OL441892 & OL441948 & OL442004 & OL442047 \\
\hline CMW54359 & N. parvum & Mangifera indica & Tshipise & OL441893 & OL441949 & OL442005 & OL442048 \\
\hline CMW54360 & N. parvum & Mangifera indica & Tshikundamalema & OL441894 & OL441950 & OL442006 & OL442049 \\
\hline CMW57467 & Oblongocollomyces sp. 1 & Sclerocarya birrea & Mapungubwe & OL441905 & OL441961 & OL442017 & OL442060 \\
\hline CMW57572 & Oblongocollomyces sp. 1 & Sclerocarya birrea & Mapungubwe & OL441906 & OL441962 & OL442018 & OL442061 \\
\hline CMW57465 & Oblongocollomyces sp. 2 & Sclerocarya birrea & Mapungubwe & OL441907 & OL441963 & OL442019 & OL442062 \\
\hline
\end{tabular}




\subsection{DNA Extraction, PCR Amplification and Sequencing}

Isolates selected for preliminary identification were grown on $2 \%$ MEA for 7 days and incubated at $25^{\circ} \mathrm{C}$, from which mycelia were scraped and freeze-dried. Freeze-dried mycelia were ground into powder and DNA was extracted following the protocol published by Möller et al. [27]. The resulting DNA pellets were re-suspended in $50 \mu \mathrm{L}$ sterile SABAX water (SABAX; Adcock Ingram, Bryanston, S.A). DNA was stained with GelRed ${ }^{\circledR}$ (Biotium, Haward, CA, USA) and visualized under UV light after electrophoresis on $1 \%$ agarose gel. DNA concentrations were determined using a NanoDrop ${ }^{\circledR}$ ND-1000 Spectrophotometer (Thermo Fisher Scientific, Wilmington, NC, USA) and adjusted to a working concentration of $50 \mathrm{ng} \mu \mathrm{L}^{-1}$ using SABAX water.

Four gene regions that are commonly used in the systematics of Botryosphaeriaceae were amplified, including the internal transcribed spacer (ITS), translation elongation factor $(t e f 1-\alpha), \beta$-tubulin $(\beta-t u b)$ and the RNA polymerase II subunit (rpb2). The ITS region that includes the ITS-1 spacer, 5.8S gene and ITS-2 spacer was amplified and sequenced for all the 78 isolates selected as representatives for the different morphological groups using primer pairs ITS-1 (5'-TCCGTAGGTGAACCTGCGG-3') and ITS-4 (5'-TCCTCCGCTTATTGATATGC-3') [28]. A subset of 29 isolates was selected based on the ITS phylogeny and analysed using other gene regions for phylogenetic confirmation of species identity. For these isolates, the translation elongation factor $($ tef1- $\alpha)$, using primer pairs tef1-728F (5'-CATCGAGAAGTTCGAGAAGG-3') and tef1-986R (5'-TAC TTG AAG GAA CCC TTA CC-3') [29], ßeta-tubulin $(\beta-t u b)$ gene using primers Bt2a $\left(5^{\prime}\right.$ GGTAACCAAATCGGTGCTGCTTTC-3') and Bt2b (5'-ACCCTCAGTGTAGTGACCCTTG GC-3') [30], as well as the RNA polymerase II subunit ( $r p b 2)$ gene using primer pairs $r p b 2-$ LasF (5'-GGTAGCGACGTCACTCCT-3') and rpb2-LasR (5'-GCGCAAATACCCAGAATCAT$\left.3^{\prime}\right)$ [31] and $r p b 2$ bot6F (5'-GGTAGCGACGTCACTCCC-3') and rpb2bot7R (5'-GGATGGATC TCGCAATGCG-3') [32] were amplified and sequenced.

PCR reactions consisted of $\sim 40-50 \mathrm{ng}$ genomic DNA, $0.2 \mu \mathrm{M}$ of each primer, $0.5 \mathrm{U}$ of MyTaq ${ }^{\mathrm{TM}}$ DNA polymerase (Bioline, London, UK), $5 \mu \mathrm{L}$ MyTaq PCR reaction buffer (10 mM Tris- $\mathrm{HCl}$ [pH 8.3], $3.0 \mathrm{mM} \mathrm{MgCl}$, $50 \mathrm{mM} \mathrm{KCl}$, Roche Diagnostics, Mannheim, Germany) and PCR grade water to a final volume of $25 \mu \mathrm{L}$. PCR cycling conditions were 2 min at $94{ }^{\circ} \mathrm{C}$, followed by 30 cycles at $94{ }^{\circ} \mathrm{C}$ for $30 \mathrm{sec}$, annealing at $54{ }^{\circ} \mathrm{C}$ (ITS and rpb2) and $56{ }^{\circ} \mathrm{C}$ (tef1- $\alpha$ and $\beta$-tub) for $30 \mathrm{sec}$, extension for $1 \mathrm{~min}$ at $72{ }^{\circ} \mathrm{C}$ and final extension for $7 \mathrm{~min}$ at $72{ }^{\circ} \mathrm{C}$. PCR products were separated on $1 \%$ agarose gel stained with GelRed ${ }^{\circledR}$ and visualised under UV light. Amplicons were purified with Exosap (Mixture of Exonuclease I and FastAP Alkaline Phosphatase) (Thermo Fisher Scientific Inc. Waltham, MA, USA) following the manufacturer's specifications. Purified PCR fragments were sequenced in both directions using the same primer pairs utilised in PCR reactions. Sequencing reactions

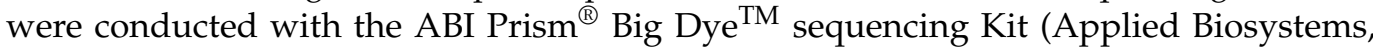
Foster City, CA, USA). Sequencing of the amplicons was done at the sequencing facility of the University of Pretoria. Consensus sequences were built from the forward and reverse sequence reads using CLC Main Workbench v.7.9 (QIAGEN, Aarhus, Denmark).

\subsection{DNA Sequence and Phylogenetic Analyses}

Sequences generated in this study were subjected to BLASTn searches against sequences on GenBank (http:/ / www.ncbi.nlm.nih.gov/genbank/) (accessed on 25 February 2019) for preliminary identification. To confirm species identity, phylogenetic analyses were performed individually for each locus dataset. Reference sequences showing similarity to query sequences in BLASTn searches were retrieved from GenBank. Sequences were aligned using an online interface of MAFFT v.7 server [33]. Alignments were verified and manual adjustments were made where necessary. The best nucleotide substitution model for each dataset was determined with jModelTest v.0.1.1 [34] using the Akaike Information Criterion (AIC) to select the model that optimally fits the data. The models $\mathrm{HKY}+\mathrm{I}+\mathrm{G}$, $\mathrm{HKY}+\mathrm{G}, \mathrm{GTR}+\mathrm{G}$ and GTR + G were applied to the ITS, tef1- $\alpha, \beta$-tub, rpb2 datasets, respectively. Maximum likelihood (ML) phylogenetic analyses were performed for the four 
datasets using RAxML v.8 [35]. To determine the robustness of the trees, bootstrap analyses were done using 1000 replicates.

Bayesian inference (BI) of phylogenetic trees was done using MrBayes v.3.2.6 [36]. Four simultaneous Markov chains were run for 3000000 generations and trees were sampled every 100th generation. The first 7500 trees representing the burn-in phase of the analyses were discarded and the remaining 22500 trees were used for calculating posterior probabilities (PP) based on a majority rule consensus tree. Effective sampling size (ESS) values were assessed using Tracer v.1.7.1 (http:/ / tree.bio.ed.ac.uk/software/tracer/) (accessed on 23 February 2021). Both the ML and BI phylogenetic trees were rooted to sequences of Melanops tulasnei (Botryosphaeriales; Melanopsaceae) as the outgroup taxa.

\section{Results}

\subsection{Tree Health Assessment}

Asymptomatic branches were collected from 191 S. birrea, 129 L. schweinfurthii and 84 M. indica trees in disturbed (Tshikundamalema and Tshipise) and undisturbed (Nwanedi, Mapungubwe and Kruger National Parks) ecosystems of the Limpopo and Mpumalanga provinces, South Africa.

Sclerocarya birrea trees were the most damaged, followed by L. schweinfurthii and M. indica (Table 2). Results obtained from the $\chi^{2}$ test indicated a statistically significant correlation between health status and tree species $(p=0.00)$. Physical damage caused by elephants was evident on S. birrea and L. schweinfurthii trees at the two National Park sites (Figure 1).

Table 2. Health status of the three tree species of Anacardiaceae assessed in this study.

\begin{tabular}{lcccc}
\hline \multicolumn{1}{c}{ Health Status } & S. birrea & M. indica & L. schweinfurthii & Total \\
\hline $0=$ healthy & 6 & 0 & 0 & 6 \\
$1=<25 \%$ dieback branches & 117 & 17 & 81 & 215 \\
$2=25-50 \%$ dieback branches & 52 & 55 & 34 & 141 \\
$3=>50 \%$ dieback branches & 12 & 12 & 9 & 33 \\
$4=$ appearing to be dying or nearly & 4 & 0 & 5 & 9 \\
dead & 191 & 84 & 129 & 404 \\
Total & & & & \\
\hline
\end{tabular}

Kruger National Park had the highest number of infected trees, followed by Tshikundamalema, Mapungubwe National Park and Tshipise. Nwanedi had the least number of infected trees (Table 3). Statistical analyses indicated that there is an association between health status and site $(p=0.00)$.

Table 3. Health status of the Anacardiaceae at the five sites sampled in this study.

\begin{tabular}{|c|c|c|c|c|c|c|}
\hline & Healthy & $\begin{array}{c}<25 \% \text { Dieback } \\
\text { Branches }\end{array}$ & $\begin{array}{c}25-50 \% \\
\text { Dieback } \\
\text { Branches }\end{array}$ & $\begin{array}{c}>50 \% \text { Dieback } \\
\text { Branches }\end{array}$ & $\begin{array}{l}\text { Appearing to } \\
\text { Be Dying or } \\
\text { Nearly Dead }\end{array}$ & Total \\
\hline Tshikundamalema & 0 & 51 & 42 & 10 & 0 & 103 \\
\hline Tshipise & 0 & 24 & 24 & 2 & 0 & 50 \\
\hline Nwanedi & 0 & 28 & 2 & 0 & 0 & 30 \\
\hline Mapungubwe & 6 & 11 & 26 & 7 & 4 & 54 \\
\hline Kruger & 0 & 101 & 47 & 14 & 5 & 167 \\
\hline
\end{tabular}




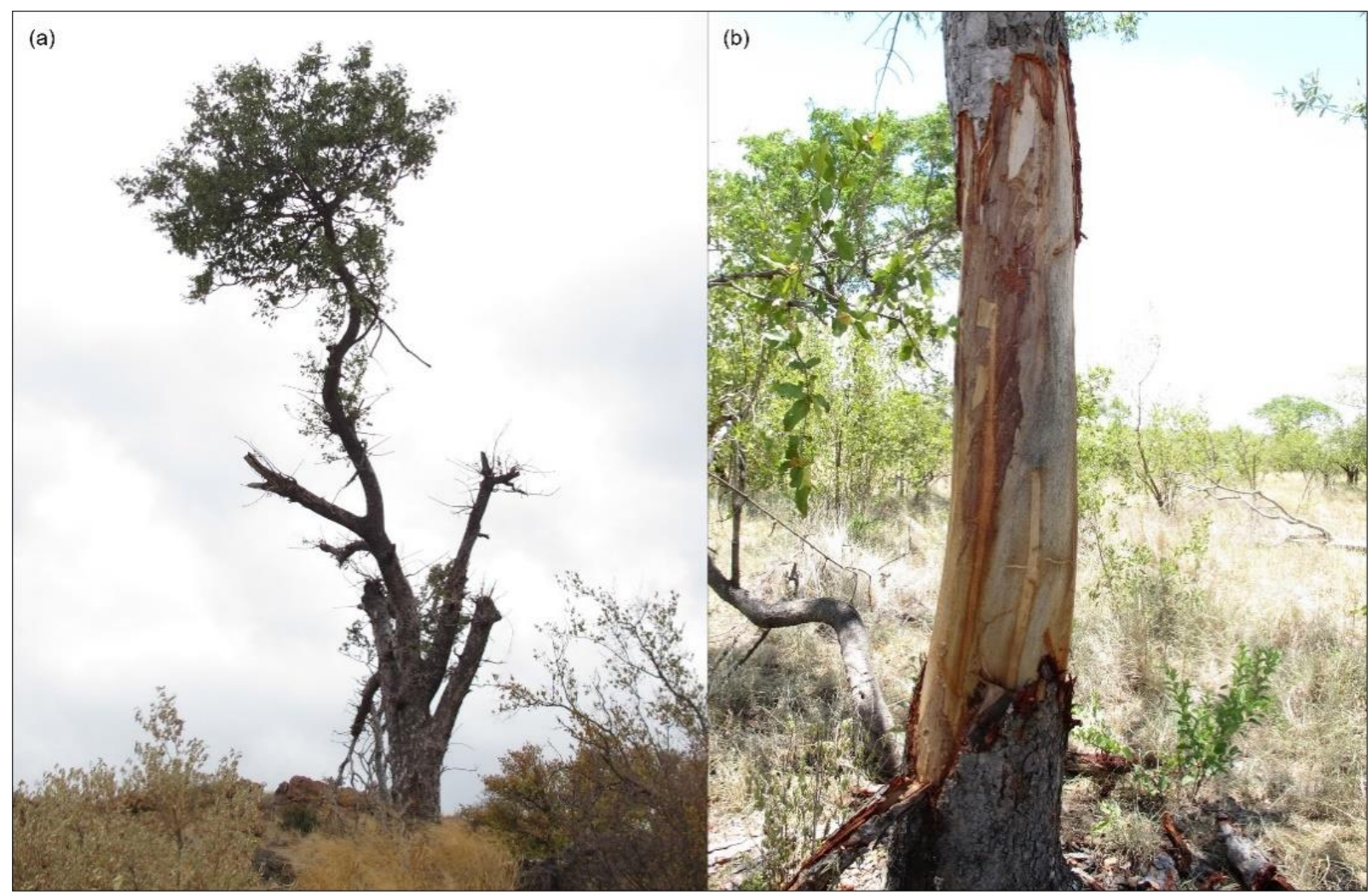

Figure 1. Trees with dieback and damage by elephants at the two National Parks; (a) Damaged Sclerocarya birrea tree at Mapungubwe National Park; (b) Bark stripped Lannea schweinfurthii tree at Kruger National Park.

\subsection{Fungal Isolation and Preliminary Identification}

A total of 404 Botryosphaeriaceae like isolates (based on culture morphology and colour characteristics) were obtained from the three hosts; 192 from S. birrea, 112 from L. Schweinfurthii and 100 from M. indica. Eleven culture morphogroups were made from these isolates.

\subsection{Phylogenetic Analyses and Confirmation of Species Identification}

From the 11 cultural morphogroups, 78 isolates were selected for preliminary ITS identification and selection of related reference sequences from GenBank. From these, 29 isolates were selected to represent the genetic diversity represented in the ITS sequences, and three additional gene regions were sequenced.

The datasets for the ITS, tef- $1 \alpha$ and $\beta$-tub gene regions included 29 isolates obtained in this study and 63 representatives from GenBank for ITS, 60 for tef- $1 \alpha$ and 54 for $\beta$-tub (Table 4). The $r p b 2$ dataset included 23 sequences generated in this study. This was because amplicons for the $r p b 2$ gene region could not be obtained for Dothiorella isolates even after using two primer sets.

The topologies of the trees generated from ML and BI analyses of the four datasets were similar in the separation of clades representing genera of Botryosphaeriaceae. However, some clades of interest did not receive bootstrap (BS) and posterior probability (PP) support. Some isolates obtained in this study failed to show the same groupings found in other phylogenetic trees and were not considered congruent. For example, the Lasiodiplodia sub-clade (including L. citricola, L. magnoliae, L. pseudotheobromae and L. vaccinii) on the ITS phylogeny (Figure 2). Most isolates on the tef-1 $\alpha$ phylogeny did not form monophyletic clades with species of Botryosphaeriaceae (Figure 3). Some rearrangements were also observed in the backbone of individual gene trees, such as the position of the clade accommodating isolates corresponding to L. crassispora on the $\beta$-tub phylogeny (Figure 4). The most variable locus 
was rpb2 which could distinguish between most species of Botryosphaeriaceae (Figure 5). Five main clades corresponding to Diplodia, Dothiorella, Lasiodiplodia, Neofusicoccum and Oblongocollomyces/Sphaeropsis were identified.

Table 4. Reference sequences obtained from GenBank and used for phylogenetic analyses in this study (species names are as indicated in the GenBank record).

\begin{tabular}{|c|c|c|c|c|c|c|}
\hline \multirow[t]{2}{*}{ Species } & \multirow[t]{2}{*}{ Country } & \multirow[t]{2}{*}{ Strain Number } & \multicolumn{4}{|c|}{ GenBank } \\
\hline & & & ITS & tef1- $\alpha$ & $r p b 2$ & $\beta-t u b$ \\
\hline Diplodia allocellula & South Africa & $\begin{array}{l}\text { CBS } 130408 \\
\text { CMW } 36468\end{array}$ & JQ239397 & JQ239384 & None & JQ239378 \\
\hline D. allocellula & South Africa & CMW 36469 & NR_111701 & JQ239385 & None & JQ239379 \\
\hline D. eriobotryicola & Spain & CBS 140851 & NR_152462 & KT240193 & None & MG015806 \\
\hline D. sapinea & Netherlands & CBS 393.84 & DQ458895 & DQ458880 & None & DQ458863 \\
\hline D. sapinea & South Africa & CBS 109726 & KX464094 & KX464568 & KX463956 & KX464800 \\
\hline D. sapinea & Australia & CBS 189.37 & KX464099 & KX464573 & KX463957 & KX464808 \\
\hline $\begin{array}{l}\text { Dothiorella } \\
\text { brevicollis }\end{array}$ & South Africa & CMW 36464 & JQ239404 & JQ239391 & None & JQ239372 \\
\hline Do. brevicollis & South Africa & $\begin{array}{l}\text { CBS } 130411 \\
\text { CMW } 36463\end{array}$ & NR_111703 & JQ239390 & None & JQ239371 \\
\hline Do. dulcispinae & South Africa & CMW 36461 & JQ239401 & JQ239388 & None & JQ239374 \\
\hline Do. dulcispinae & Namibia & CMW 36460 & NR_111702 & JQ239387 & None & JQ239373 \\
\hline Do. longicollis & Australia & $\begin{array}{l}\text { CBS } 122068 \\
\text { CMW } 26166\end{array}$ & NR_136999 & EU144069 & KX463972 & KF766246 \\
\hline Do. longicollis & Australia & CMW 26165 & EU144053 & EU144068 & None & None \\
\hline Do. oblonga & South Africa & $\begin{array}{l}\text { CBS } 121765 \\
\text { CMW } 25407\end{array}$ & EU101301 & EU101345 & None & KX464862 \\
\hline Do. oblonga & South Africa & $\begin{array}{l}\text { CBS } 121766 \\
\text { CMW } 25408\end{array}$ & NR_137689 & EU101346 & None & KX464863 \\
\hline Do. plurivora & Iran & $\begin{array}{l}\text { CBS } 124724 \\
\text { IRAN 1557C }\end{array}$ & KC 898225 & KC898208 & None & KX464874 \\
\hline Do. plurivora & USA, California & CBS 120999 & KX464125 & KX464617 & None & KX464870 \\
\hline Do. pretoriensis & South Africa & $\begin{array}{l}\text { CBS } 130404 \\
\text { CMW } 36480\end{array}$ & JQ239405 & JQ239392 & None & JQ239376 \\
\hline Do. pretoriensis & South Africa & CMW 36481 & JQ239406 & JQ239393 & None & JQ239377 \\
\hline Do. viticola & South Africa & CMW 37928 & JX283730 & JX283741 & None & JX283717 \\
\hline Do. viticola & South Africa & CMW 37933 & JX283735 & JX283743 & None & JX283719 \\
\hline Do. viticola & Spain & CBS 117009 & MH863011 & AY905559 & DQ677985 & EU673104 \\
\hline Do. viticola & South Africa & STE-U5048 & AY343373 & AY343336 & EF204479 & None \\
\hline L. americana & USA, Arizona & $\begin{array}{l}\text { CERC } 1962 \\
\text { CFCC } 50066\end{array}$ & KP217060 & KP217068 & None & KP217076 \\
\hline
\end{tabular}


Table 4. Cont.

\begin{tabular}{|c|c|c|c|c|c|c|}
\hline \multirow[t]{2}{*}{ Species } & \multirow[t]{2}{*}{ Country } & \multirow[t]{2}{*}{ Strain Number } & \multicolumn{4}{|c|}{ GenBank } \\
\hline & & & ITS & tef1- $\alpha$ & $r p b 2$ & $\beta-t u b$ \\
\hline L. americana & USA, Arizona & $\begin{array}{c}\text { CERC } 1961 \\
\text { CFCC } 50065\end{array}$ & KР217059 & KР217067 & None & KP217075 \\
\hline $\begin{array}{l}\text { Lasiodiplodia } \\
\text { chonburiensis }\end{array}$ & Thailand & $\begin{array}{l}\text { MFLUCC } \\
16-0376\end{array}$ & MH275066 & MH412773 & None & MH412742 \\
\hline L. citricola & Iran & IRNKB3 & MN634040 & MN633994 & None & None \\
\hline L. citricola & Iran & $\begin{array}{l}\text { CBS } 124707 \\
\text { IRAN 1522C }\end{array}$ & GU945354 & GU945340 & KP872455 & KU887505 \\
\hline L. citricola & Iran & $\begin{array}{l}\text { CBS } 124706 \\
\text { IRAN 1521C }\end{array}$ & GU945353 & GU945339 & KP872456 & KU887504 \\
\hline L. crassispora & Venezuela & CMW 13488 & DQ103552 & DQ103559 & KP872458 & KU887507 \\
\hline L. crassispora & Australia & $\begin{array}{l}\text { CBS } 118741 \\
\text { WAC } 12533\end{array}$ & NR_111194 & EU673303 & KP872457 & KU887506 \\
\hline L. exigua & Tunisia & $\begin{array}{l}\text { CBS } 137785 \\
\text { BL104 }\end{array}$ & KJ638317 & KJ638336 & KU696355 & KU887509 \\
\hline L. exigua & Tunisia & BL184 & KJ638318 & KJ638337 & None & None \\
\hline L. gonubiensis & South Africa & $\begin{array}{l}\text { CBS } 115812 \\
\text { CMW } 14077\end{array}$ & DQ458892 & DQ103566 & KP872464 & KU887512 \\
\hline L. gonubiensis & South Africa & $\begin{array}{l}\text { CBS } 116355 \\
\text { CMW } 14078\end{array}$ & AY639594 & DQ103567 & KP872465 & KU887513 \\
\hline L. lignicola & Thailand & $\begin{array}{l}\text { MFLUCC } \\
11-0435\end{array}$ & JX646797 & KP872375 & KP872470 & JX646845 \\
\hline L. lignicola & India & SUF161 & MT081525 & None & None & None \\
\hline L. magnoliae & China & $\begin{array}{l}\text { MFLUCC } \\
18-0948\end{array}$ & MK499387 & MK568537 & None & MK521587 \\
\hline L. mahajangana & Madagascar & CMW 27801 & FJ900595 & FJ900641 & KP872471 & FJ900630 \\
\hline L. mahajangana & Madagascar & CMW 27818 & FJ900596 & FJ900642 & KU696366 & FJ900631 \\
\hline L. margaritacea & Australia & $\begin{array}{l}\text { CBS } 122519 \\
\text { CMW } 26162\end{array}$ & NR_136998 & EU144065 & KP872473 & KX464903 \\
\hline L. pandanicola & Thailand & $\begin{array}{l}\text { MFLUCC } \\
16-0265\end{array}$ & MH275068 & MH412774 & None & None \\
\hline L. pandanicola & China & GBLZ16BO-008 & MN540679 & None & None & MN539183 \\
\hline $\begin{array}{c}\text { L. } \\
\text { pseudotheobromae }\end{array}$ & Costa Rica & $\begin{array}{l}\text { CBS } 116459 \\
\text { CMW } 40939\end{array}$ & EF622077 & EF622057 & KU696376 & EU673111 \\
\hline
\end{tabular}


Table 4. Cont.

\begin{tabular}{|c|c|c|c|c|c|c|}
\hline \multirow[t]{2}{*}{ Species } & \multirow[t]{2}{*}{ Country } & \multirow[t]{2}{*}{ Strain Number } & \multicolumn{4}{|c|}{ GenBank } \\
\hline & & & ITS & tef1- $\alpha$ & $r p b 2$ & $\beta-t u b$ \\
\hline $\begin{array}{c}\text { L. } \\
\text { pseudotheobromae }\end{array}$ & Zaire & CBS 374.54 & KX464139 & KX464633 & None & KX464906 \\
\hline $\begin{array}{c}\text { L. } \\
\text { pseudotheobromae }\end{array}$ & China & $\begin{array}{c}\text { BJFU } \\
\text { ZYP151106-14 }\end{array}$ & KX499902 & KX499940 & KX499977 & None \\
\hline L. pyriformis & Namibia & $\begin{array}{l}\text { CBS } 121771 \\
\text { CMW } 25415\end{array}$ & EU101308 & EU101353 & KU696379 & KU887528 \\
\hline L. pyriformis & Namibia & CMW 25416 & EU101309 & EU101354 & None & None \\
\hline L. pyriformis & Namibia & $\begin{array}{l}\text { CBS } 121770 \\
\text { CMW } 25414\end{array}$ & NR_136993 & EU101352 & KP872483 & KU887527 \\
\hline L. theobromae & $\begin{array}{c}\text { Papua New } \\
\text { Guinea }\end{array}$ & $\begin{array}{c}\text { CBS } 164.96 \\
\text { CMW } 50942 \\
\end{array}$ & AY640255 & AY640258 & KU696383 & KU887532 \\
\hline L. theobromae & unknown & CBS 111530 & EF622074 & EF622054 & KU696382 & None \\
\hline L. vaccinii & China, Beijing & $\begin{array}{c}\text { CGMCC } \\
3.19022 \\
\end{array}$ & MH330318 & МH330327 & МH330321 & MH330324 \\
\hline L. vaccinii & China, Beijing & CGMCC3.19256 & MK157139 & MK157166 & MK157148 & MK157157 \\
\hline $\begin{array}{l}\text { Neofusicoccum } \\
\text { parvum }\end{array}$ & South Africa & CMW 41213 & KР860849 & KР860693 & KU587896 & KP860771 \\
\hline N. paroum & New Zealand & $\begin{array}{l}\text { CBS } 138823 \\
\text { CMW } 9081\end{array}$ & NR_119487 & AY236888 & EU821963 & AY236917 \\
\hline N. ribis & USA, New York & CMW 7772 & AY236935 & AY236877 & EU863170 & AY236906 \\
\hline N. ribis & USA, New York & CMW 7773 & AY236936 & AY236878 & EU863169 & AY236907 \\
\hline N. umdonicola & South Africa & CMW 14058 & EU821904 & EU821874 & EU821934 & EU821844 \\
\hline N. umdonicola & South Africa & $\begin{array}{l}\text { CBS } 123646 \\
\text { CMW } 14060\end{array}$ & EU821905 & EU821875 & EU821935 & KF766145 \\
\hline $\begin{array}{c}\text { Oblongocollomyces } \\
\text { variabilis }\end{array}$ & Namibia/RSA & CMW 36482 & JX283726 & JX283738 & None & JX283714 \\
\hline O. variabilis & Namibia & $\begin{array}{l}\text { CBS } 121774 \\
\text { CMW } 25419\end{array}$ & NR_136994 & EU101357 & KX464053 & JX283715 \\
\hline Sphaeropsis porosa & South Africa & $\begin{array}{l}\text { CBS } 110496 \\
\text { CPC } 5132\end{array}$ & NR_119492 & AY343340 & KX464076 & EU673130 \\
\hline Melanops tulasnei & Germany & CBS 116805 & FJ824769 & None & None & FJ824780 \\
\hline M. tulasnei & Germany & CBS 116806 & FJ824770 & FJ824775 & KX463998 & FJ824781 \\
\hline
\end{tabular}




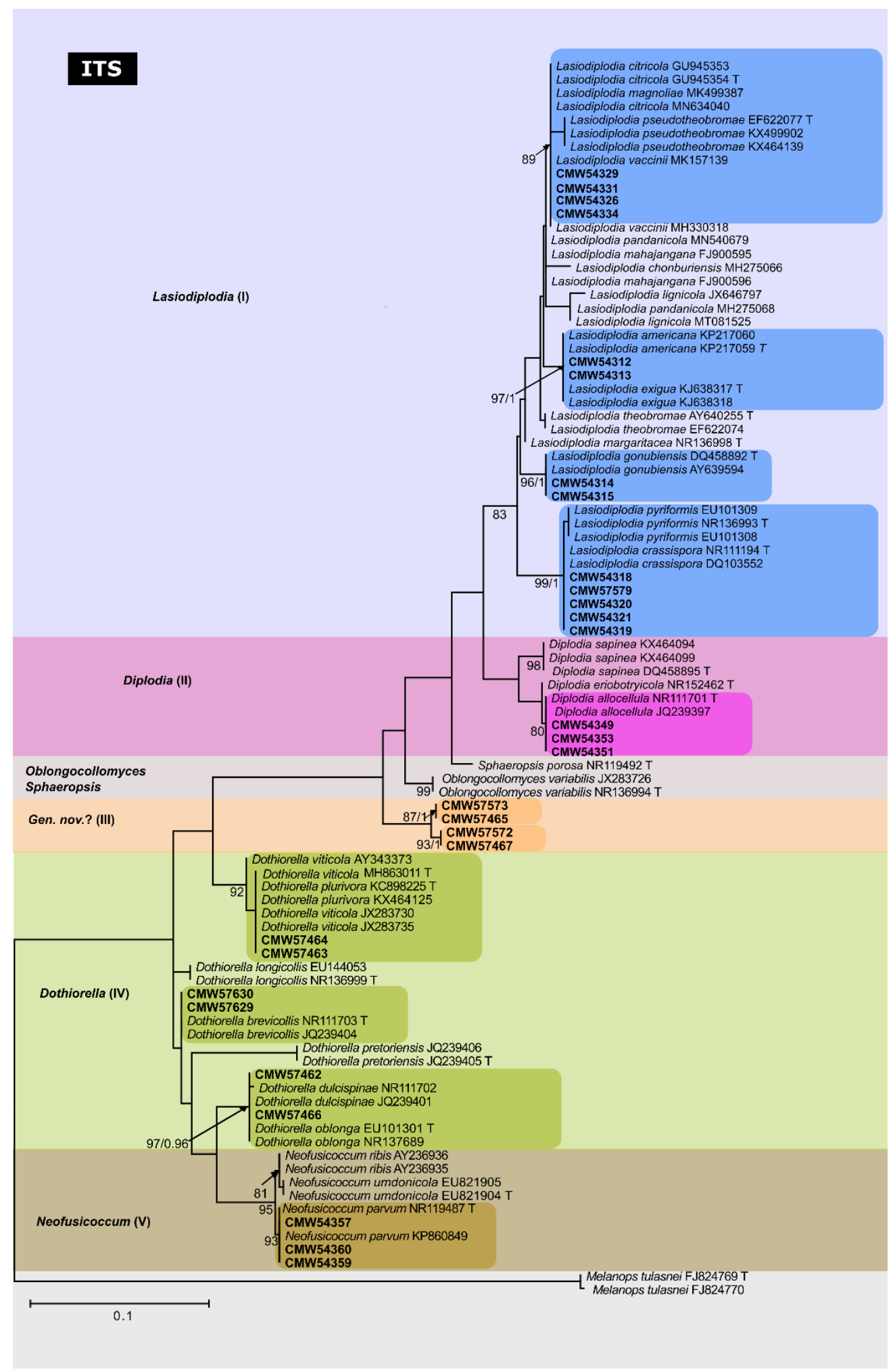

Figure 2. Maximum likelihood (ML) phylogenetic tree resulting from analyses of the ITS dataset. Bootstrap support values above $70 \%$ and Bayesian posterior probability values above 0.95 are shown at the nodes. Isolates in bold were obtained in this study. The tree was rooted to Melanops tulasnei. 


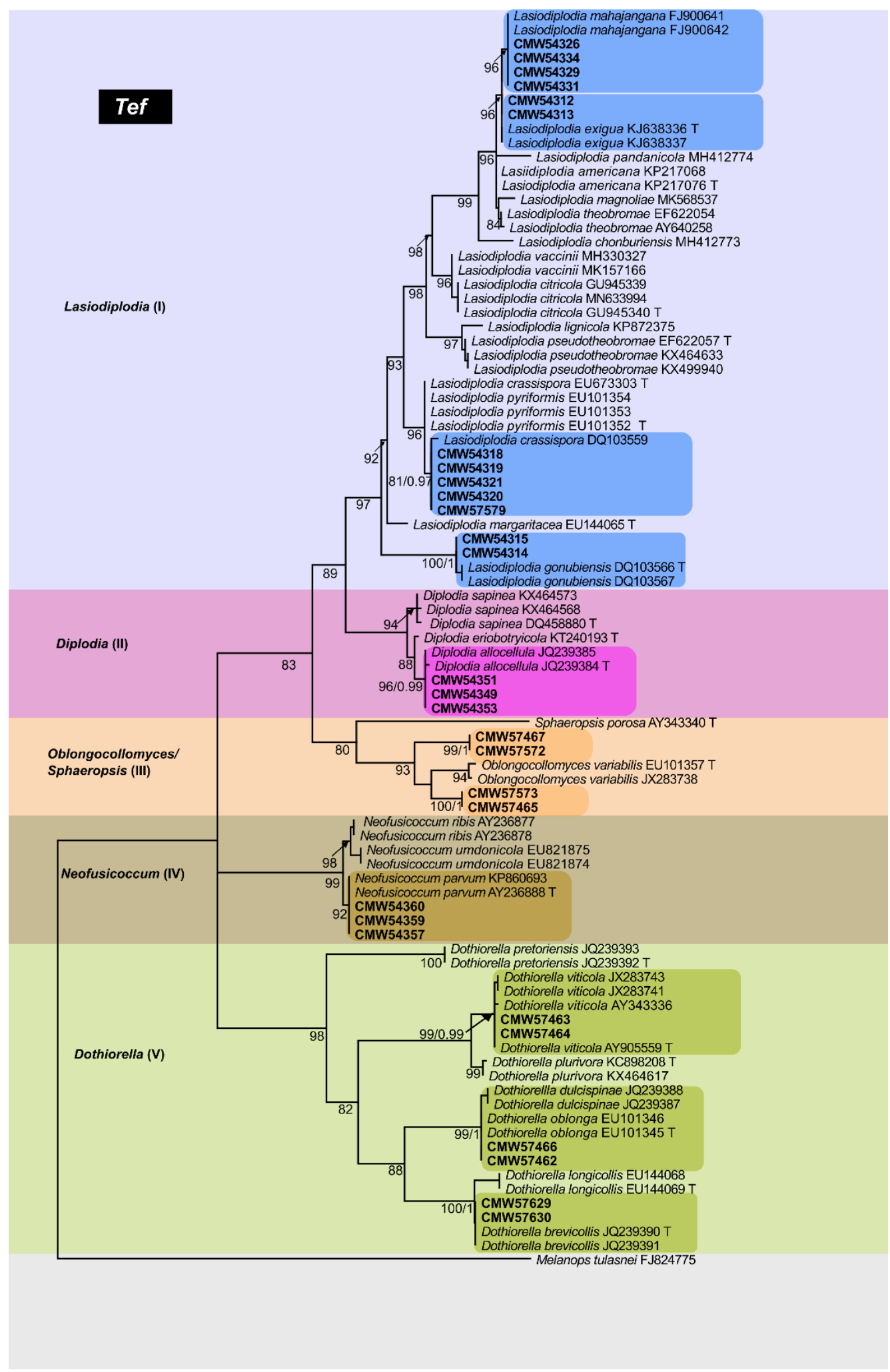

Figure 3. Maximum likelihood phylogenetic tree obtained from analyses of the tef- $1 \alpha$ data including species of Botryosphaeriaceae. Bootstrap values $>70 \%$ and posterior probabilities values $>0.95$ are shown at the nodes. Isolates in bold were obtained during this study. The tree was rooted to an isolate of Melanops tulasnei. 


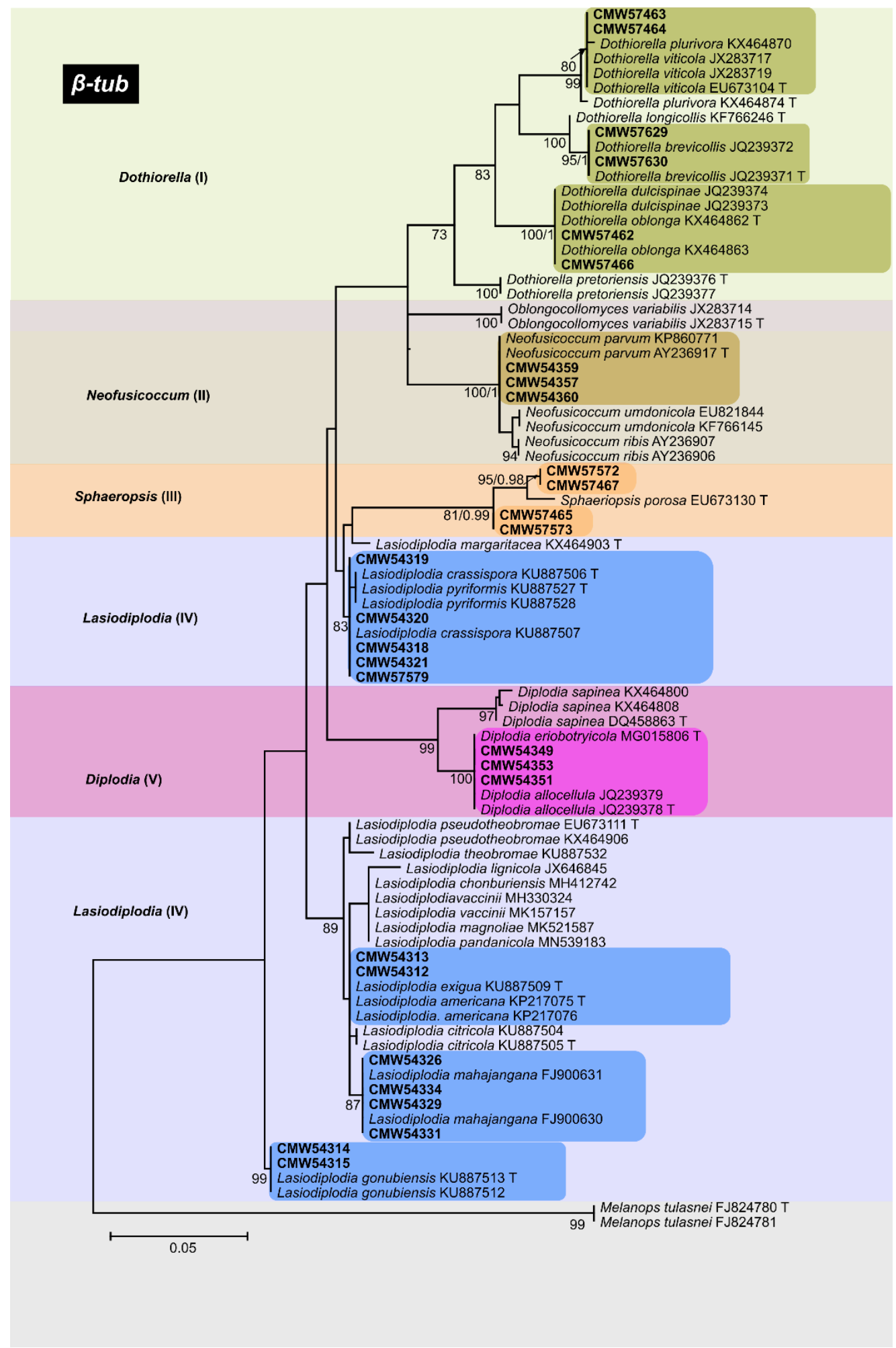

Figure 4. Phylogenetic tree obtained from ML and BI analyses of the $\beta$-tub dataset. Bootstrap values $(>70 \%)$ and PP values (>0.95) appear at the nodes. Isolates in bold were obtained during this study. The tree was rooted to isolates of Melanops tulasnei. 


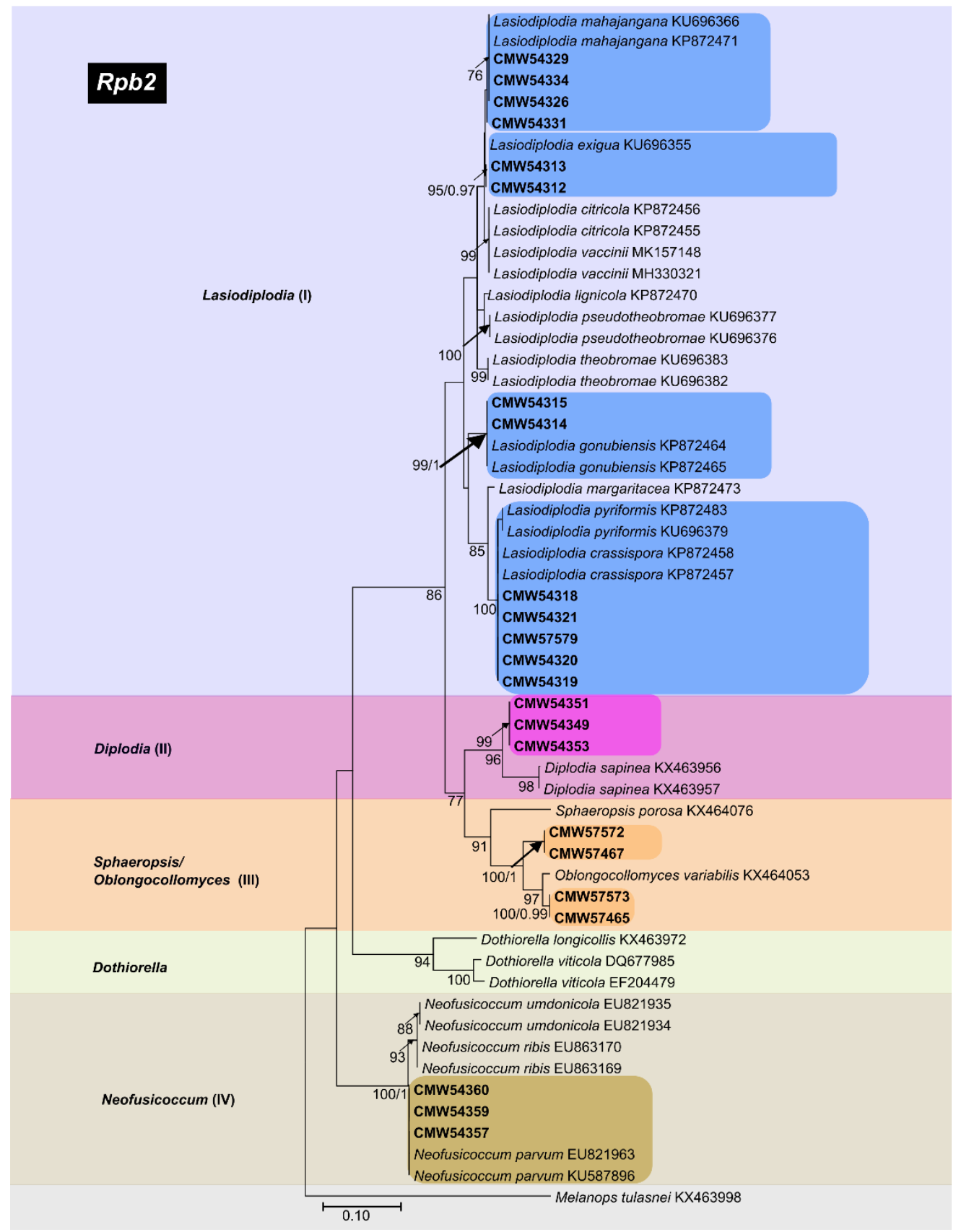

Figure 5. Maximum likelihood (ML) phylogenetic tree based on analyses of the $r p b 2$ dataset showing relationship between isolates obtained in this study (in bold) and species of Botryosphaeriaceae. Bootstrap values $(>70 \%)$ and PP values ( $>0.95)$ appear at the nodes. The tree was rooted to an isolate of Melanops tulasnei.

\subsubsection{ITS Phylogeny}

The phylogeny obtained from ML and BI analyses of the ITS sequence dataset grouped isolates obtained in this study into five clades representing five genera of Botryosphaeriaceae (Figure 2). The five clades represented Lasiodiplodia (clade I), Diplodia (clade II), Oblongocollomyces / Sphaeropsis (clade III), Dothiorella (clade IV) and Neofusicoccum (clade V). In the Lasiodiplodia clade, four isolates (CMW54326, CMW54329, CMW54331 and CMW54334) could not be identified. These isolates clustered with L. citricola, L. magnoliae, L. pseudotheobromae and L. vaccinii. Isolates CMW54312 and CMW54313 grouped with L. americana and L. exigua. Two isolates, CMW54314 and CMW54315 formed a monophyletic clade with L. gonubiensis. Isolates CMW54318, CMW54319, CMW54320, CMW54321 and CMW57579 
formed a polytomy with $L$. crassispora, separate from L. pyriformis. The Diplodia clade included D. allocellula, D. eriobotryicola and D. sapinea sequences. Three isolates obtained in this study (CMW54349, CMW54351 and CMW54353) formed a polytomy with D. allocellula, separate from D. eriobotrycola. Clade III included four isolates (CMW57573, CMW57465, CMW57573 and CMW57467) that formed a distinct clade from previously described species of Botryosphaeriaceae. The four isolates formed two sub-clades indicating that they possibly represent two closely related but distinct species. These isolates could not be assigned to a species based on ITS sequence data. These isolates were analyzed separately based on the ITS, tef- $1 \alpha, \beta-t u b$ and $r p b 2$ datasets (Figure S1). Clade IV included Dothiorella sequences. Two isolates, CMW57463 and CMW57464 grouped with Do. plurivora and Do. viticola. Isolates CMW57629 and CMW57630 formed a polytomy within the genus based on the ITS sequence data. Isolates CMW57462 and CMW57466 grouped with Do. dulcispinae and Do. oblonga. The Neofusicoccum clade included N. parvum, N. ribis and N. umdonicola sequences, with isolates obtained in this study (CMW54357, CMW54359 and CMW54360) corresponding to N. parvum.

\subsubsection{Tef- $1 \alpha$ Phylogeny}

The tef- $1 \alpha$ phylogeny separated sequences from the isolates obtained in this study into five clades. These clades represented Lasiodiplodia (clade I), Diplodia (clade II), Oblongocollomyces/Sphaeropsis (clade III), Neofusicoccum (clade IV) and Dothiorella (clade V) (Figure 3). The Lasiodiplodia clade included isolates (CMW54326, CMW54329, CMW54331 and CMW54334) that grouped with L. mahajangana. Two isolates, CMW54312 and CMW54313 formed a polytomy with L. exigua. Isolates CMW54318, CMW54319, CMW54320, CMW54321 and CMW57579 grouped with L. crassispora. Isolates CMW54314 and CMW54315 grouped with L. gonubiensis. The Diplodia clade included D. allocellula, D. eriobotryicola and D. sapinea sequences, with isolates obtained in this study (CMW54349, CMW54351 and CMW54353) corresponding to D. allocellula. Clade III included four isolates that could not be identified to species level based on the tef- $1 \alpha$ sequence data. Two isolates (CMW57573 and CMW57465) formed a sister clade with O. variabilis. The other two isolates (CMW57467 and CMW57572) formed a sister clade with both O. variabilis and the other two isolates (CMW57573 and CMW57465). These isolates could not be assigned to a species because $O$. variabilis is the only species in the genus, and the four isolates did not form a monophyletic group with this species. Therefore, these isolates are referred to as Oblongocollomyces sp. 1 (CMW57467 and CMW57572) and Oblongocollomyces sp. 2 (CMW57573 and CMW57465). The Neofusicoccum clade included isolates (CMW54357, CMW54359 and CMW54360) that formed a monophyletic clade with N. parvum. Clade V included Dothiorella sequences. Isolates CMW57463 and CMW57464 grouped with Do. viticola. Isolates CMW57462 and CMW57466 formed a polytomy with Do. oblonga, separate from Do. dulcispinae. Isolates CMW57629 and CMW57630 formed a polytomy with Do. brevicollis, separate from Do. longicollis.

\subsection{3. $\beta$-Tub Phylogeny}

The phylogeny emerging from ML and BI analyses of the $\beta$-tub dataset separated isolates obtained in this study into clades corresponding to five genera of Botryosphaeriaceae including Dothiorella (clade I), Neofusicoccum (clade II), Sphaeropsis (clade III), Lasiodiplodia (IV) and Diplodia (V) (Figure 4). The $\beta$-tub phylogeny varied from the other gene trees on the placement of some isolates obtained in this study. For example, the Lasiodiplodia clade including isolates corresponding to L. crassispora formed a separate clade from other Lasiodiplodia species. In the Dothiorella clade, two isolates (CMW57463 and CMW57464) grouped with Do. plurivora and Do. viticola. Isolates CMW57629 and CMW57630 grouped with Do. brevicollis. Isolates CMW57462 and CMW57466 grouped with Do. dulcispinae and Do. oblonga. The Neofusicoccum clade included N. parvum, N. ribis and N. umdonicola sequences. Isolates obtained in this study (CMW54357, CMW54359 and CMW54360) grouped with N. paroum. The four isolates (CMW57467, CMW57572, CMW57465 and CMW57573) that 
could not be assigned to a species on the ITS and tef- $1 \alpha$ phylogeny, grouped with Sphaeropsis porosa on the $\beta$-tub phylogeny. Two of these isolates (CMW57467 and CMW57572) formed a sister clade with $S$. porosa, while the other two isolates (CMW57465 and CMW57573) formed a sister clade with both $S$. porosa and the other closely related isolates (CMW57467 and CMW57572). The Lasiodiplodia clade included five isolates (CMW54318, CMW54319, CMW54320, CMW54321 and CMW57579) that grouped with L. crassispora and L. pyriformis. Clade V included Diplodia sequences. Isolates obtained in this study grouped with $D$. allocellula and D. eriobotryicola. Isolates CMW54312 and CMW54313 together with L. exigua formed a polytomy within the Lasiodiplodia genus based on the $\beta$-tub sequence data. Isolates CMW54326, CMW54329, CMW54331 and CMW54334 grouped with L. mahajangana. Isolates CMW54314 and CMW54315 formed a monophyletic clade with L. gonubiensis.

\subsection{4. rpb2 Phylogeny}

The $r p b 2$ phylogeny separated isolates obtained in this study into four clades. These clades represented Lasiodiplodia (clade I), Diplodia (clade II), Oblongocollomyces / Sphaeropsis (clade III) and Neofusicoccum (clade IV) (Figure 5). Four isolates in the Lasiodiplodia clade (CMW54326, CMW54329, CMW54331 and CMW54334) grouped with L. mahajangana. Two isolates, CMW54312 and CMW54313 grouped with L. exigua. Isolates CMW54314 and CMW54315 formed a monophyletic clade with L. gonubiensis. Isolates CMW54318, CMW54319, CMW54320, CMW54321 and CMW57579 formed a polytomy with L. crassispora, separate from L. pyriformis. The Diplodia clade included D. sapinea sequences only because reference sequences for other Diplodia species for the $r p b 2$ gene region are not available on public databases. Three isolates (CMW54349, CMW54351 and CMW54353) identified as D. allocellula on the ITS, tef1- $\alpha$ and $\beta$-tub phylogenetic trees formed a sister clade with $D$. sapinea indicating that they reside in the same genus. Clade III included $O$. variabilis and $S$. porosa sequences. Two isolates obtained in this study (CMW57465 and CMW57573) formed a sister clade with O. variabilis. The other two isolates (CMW57467 and CMW57572) formed a sister clade with both $O$. variabilis and the other two isolates (CMW57573 and CMW57465). These isolates could not be assigned to a species based on the $r p b 2$ sequence data and are, thus, referred to as Oblongocollomyces sp. 1 (CMW57467 and CMW57572) and Oblongocollomyces sp. 2 (CMW57465 and CMW57573). The Dothiorella clade did not include any isolates obtained in this study because amplicons for Dothiorella isolates could not be obtained despite efforts to sequence two different primer sets. The Neofusicoccum clade included N. parvum, N. ribis and N. umdonicola sequences. Three isolates obtained in this study (CMW54357, CMW54359 and CMW54360) grouped with N. parvum.

\subsection{Species Diversity Distribution}

The phylogenies obtained from ML and BI analyses of the four loci distinguished isolates obtained in this study as D. allocellula, Do. brevicollis, Do. dulcispinae/Do. oblonga, Do. plurivora/Do. viticola, L. americana/L. exigua, L. crassispora/L. pyriformis, L. gonubiensis, L. citricola/L. magnoliae/L. pseudotheobromae/L. vaccinii, L. mahajangana, N. parvum, Oblongocollomyces sp. 1 and Oblongocollomyces sp. 2.

Isolates CMW54312 and CMW54313 that grouped with L. americana and L. exigua are treated as L. exigua based on a previous study that reduced L. americana to synonymy with L. exigua [37]. Four isolates (CMW54326, CMW54329, CMW54331 and CMW54334) that grouped with L. citricola, L. magnoliae, L. pseudotheobromae and L. vaccinii on the ITS phylogeny grouped with L. mahajangana on the tef1- $\alpha, \beta-t u b$ and $r p b 2$ phylogenies. Therefore, these isolates are treated as L. mahajangana. Isolates CMW54318, CMW54319, CMW54320, CMW54321 and CMW57579 that grouped with L. crassispora and L. pyriformis are treated as L. crassispora as they formed unresolved groups and based on an earlier study that reduced L. pyriformis to synonymy with L. crassispora [38]. Similarly, isolates CMW57462 and CMW57466 that grouped with Do. dulcispinae and Do. oblonga are treated as Do. dulcispinae as they formed unresolved groups and based on a study that reduced Do. oblonga to synonymy with Do. dulcispinae [38]. Isolates CMW57463 and CMW57464 that 
grouped with Do. plurivora and Do. viticola are treated as Do. viticola based on analyses of the tef1- $\alpha$ sequence data.

Eleven species of Botryosphaeriaceae including D. allocellula, Do. brevicollis, Do. dulcispinae, Do. viticola, L. crassispora, L. exigua, L. gonubiensis, L. mahajangana, N. parvum, Oblongocollomyces sp. 1 and Oblongocollomyces sp. 2 were identified as endophytes on tree species of Anacardiaceae in this study. Identities of the 11 species were assigned to all 404 Botryosphaeriaceae isolates based on the combined results of the morphogroup identification and phylogenetic analyses of the ITS, tef1- $\alpha, \beta-t u b$ and $r p b 2$ sequence datasets (Table 5).

Table 5. Number of Botryosphaeriaceae isolates identified based on morphological and phylogenetic grouping.

\begin{tabular}{|c|c|c|c|}
\hline Location & Host & Identity & $\begin{array}{l}\text { Number of } \\
\text { Isolates }\end{array}$ \\
\hline \multirow[t]{3}{*}{ Tshikundamalema } & Sclerocarya birrea & Lasiodiplodia crassispora & 10 \\
\hline & & Lasiodiplodia mahajangana & 7 \\
\hline & & Neofusicoccum parvum & 3 \\
\hline \multirow[t]{3}{*}{ Tshikundamalema } & Mangifera indica & Lasiodiplodia crassispora & 28 \\
\hline & & Lasiodiplodia mahajangana & 26 \\
\hline & & Neofusicoccum parvum & 4 \\
\hline \multirow[t]{2}{*}{ Tshipise } & Sclerocarya birrea & Lasiodiplodia mahajangana & 25 \\
\hline & & Neofusicoccum parvum & 4 \\
\hline \multirow[t]{3}{*}{ Tshipise } & Mangifera indica & Lasiodiplodia crassispora & 3 \\
\hline & & Lasiodiplodia mahajangana & 5 \\
\hline & & Neofusicoccum parvum & 34 \\
\hline \multirow[t]{3}{*}{ Kruger } & Lannea schweinfurthii & Diplodia allocellula & 25 \\
\hline & & Lasiodiplodia crassispora & 27 \\
\hline & & Lasiodiplodia mahajangana & 6 \\
\hline \multirow[t]{5}{*}{ Kruger } & Sclerocarya birrea & Diplodia allocellula & 29 \\
\hline & & Dothiorella dulcispinae & 6 \\
\hline & & Lasiodiplodia crassispora & 9 \\
\hline & & Lasiodiplodia gonubiensis & 2 \\
\hline & & Lasiodiplodia mahajangana & 7 \\
\hline \multirow[t]{2}{*}{ Nwanedi } & Lannea schweinfurthii & Dothiorella brevicollis & 34 \\
\hline & & Lasiodiplodia mahajangana & 20 \\
\hline \multirow[t]{8}{*}{ Mapungubwe } & Sclerocarya birrea & Dothiorella brevicollis & 20 \\
\hline & & Dothiorella dulcispinae & 2 \\
\hline & & Dothiorella viticola & 6 \\
\hline & & Lasiodiplodia crassispora & 15 \\
\hline & & Lasiodiplodia exigua & 3 \\
\hline & & Lasiodiplodia mahajangana & 40 \\
\hline & & Oblongocollomyces sp. 1 & 2 \\
\hline & & Oblongocollomyces sp. 2 & 2 \\
\hline
\end{tabular}

The number of Botryosphaeriaceae species identified on the three tree species of Anacardiaceae varied across the different sampling sites in disturbed and undisturbed ecosystems (Figure 6). The highest species diversity was observed on S. birrea in Mapungubwe National Park with eight species identified.

There was variation in species diversity and distribution of Botryosphaeriaceae on the trees of Anacardiaceae in disturbed and undisturbed ecosystems (Figure 7). Eight species were unique to trees in undisturbed ecosystems, two occurred on trees in both disturbed and undisturbed ecosystems and only one species was unique to trees in disturbed ecosystems. 


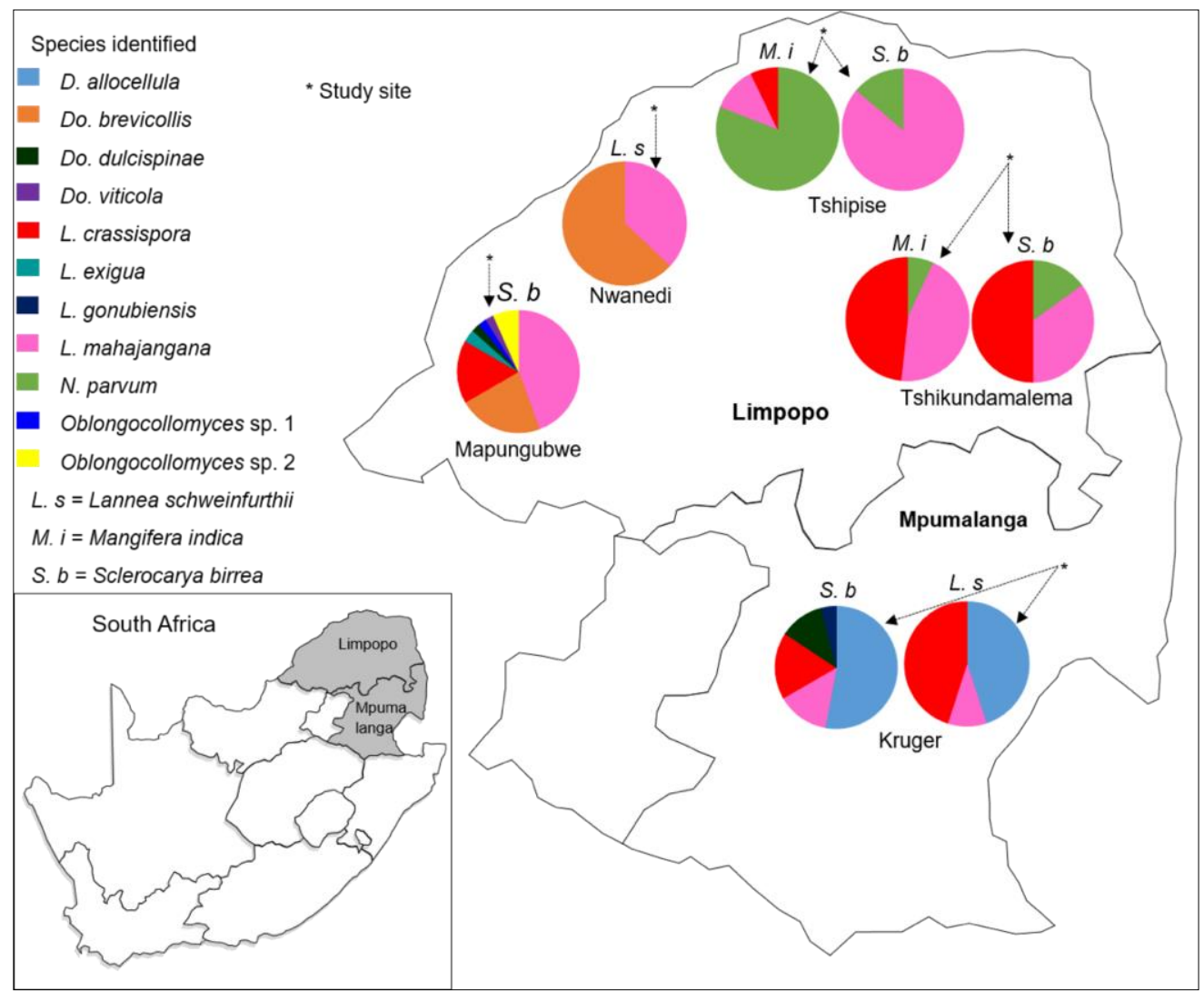

Figure 6. Map indicating species diversity and distribution of the Botryosphaeriaceae on Sclerocarya birrea, Mangifera indica and Lannea schweinfurthii trees in Mapungubwe, Nwanedi, Tshipise, Tshikundamalema and Kruger National Park. Insert: Map of South Africa with the two provinces in which the sampling sites reside shown in grey.

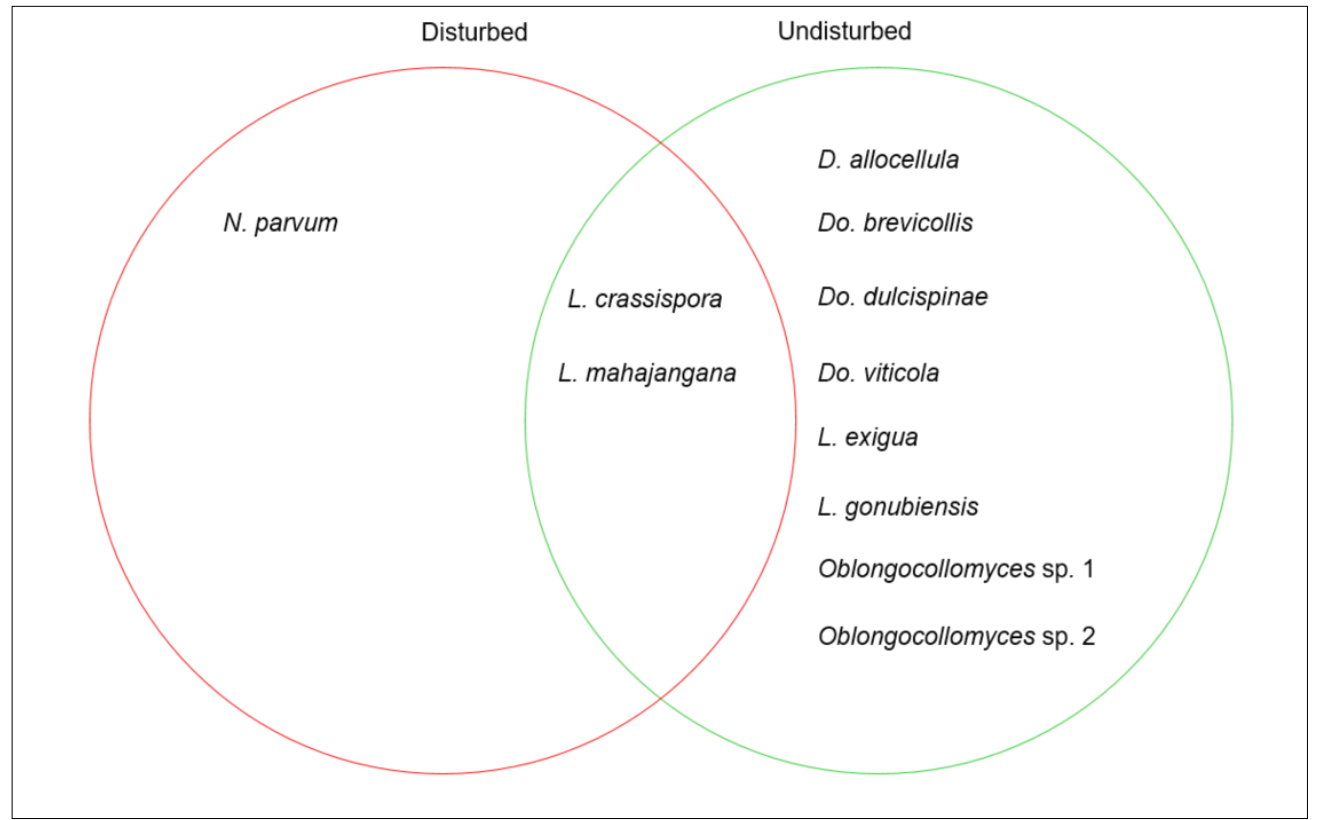

Figure 7. Venn diagram indicating species diversity and distribution of the Botryosphaeriaceae on tree species of the Anacardiaceae in disturbed (including S. birrea and M. indica at Tshikundamalema and Tshipise) and undisturbed (including S. birrea and L. schweinfurthii at Nwanedi, Mapungubwe and Kruger National Park) ecosystems. 
Some species of Botryosphaeriaceae displayed the ability to infect both native and nonnative Anacardiaceae (Figure 8). Lasiodiplodia crassispora and L. mahajangana overlapped on all three tree species of the Anacardiaceae. Neofusicoccum parvum overlapped between S. birrea (native) and $M$. indica (non-native) where they were growing next to each other at the two disturbed ecosystems. Diplodia allocellula and Do. brevicollis overlapped between native Anacardiaceae (S. birrea and L. schweinfurthii) in undisturbed ecosystems. Some species were only found on one tree species. These included Do. dulcispinae, Do. viticola, L. exigua, L. gonubiensis, Oblongocollomyces sp. 1 and Oblongocollomyces sp. 2 on S. birrea.

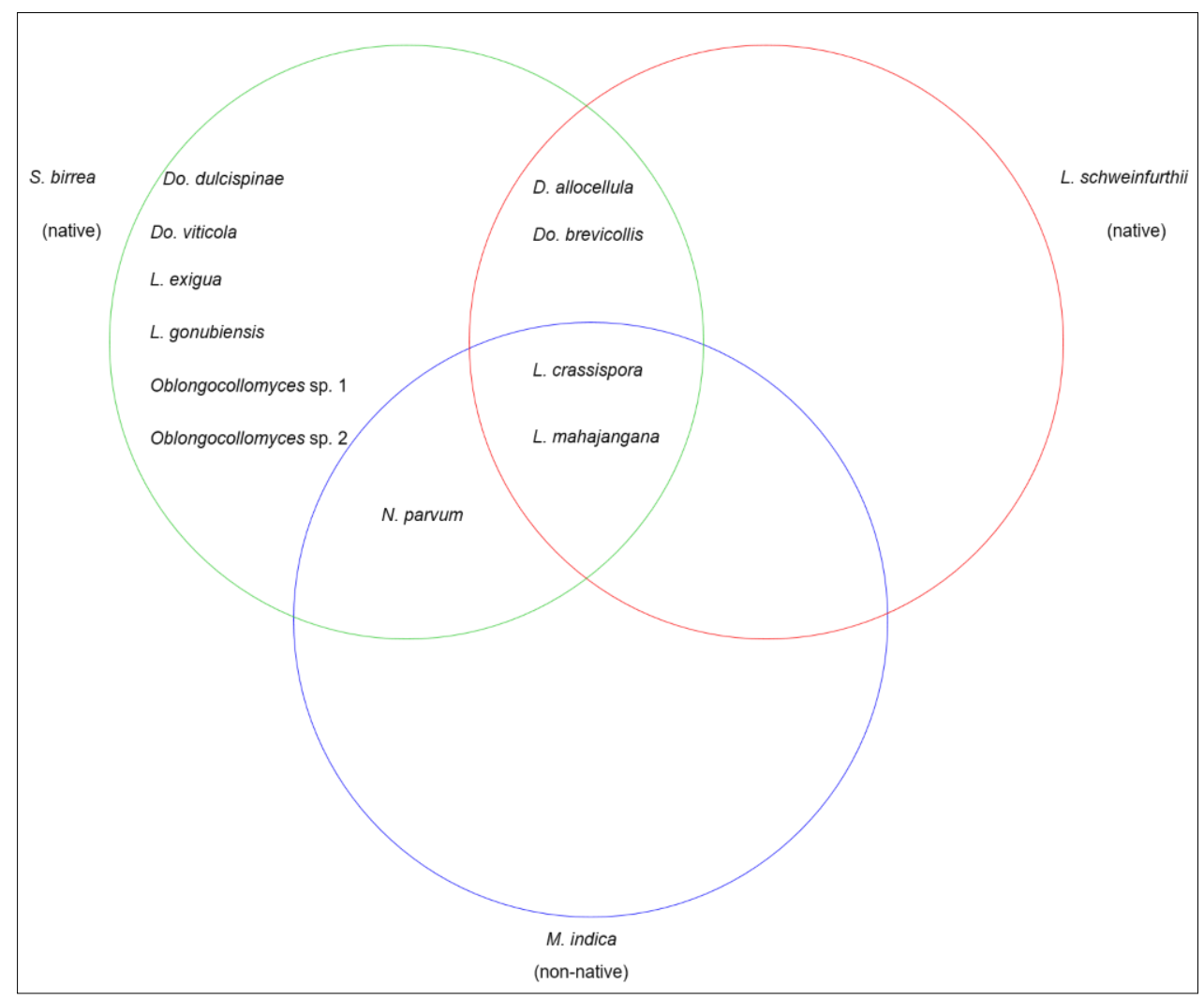

Figure 8. Venn diagram showing species overlap of Botryosphaeriaceae on Sclerocarya birrea, Lannea schweinfurthii and Mangifera indica.

\section{Discussion}

In this study, we report the presence of at least 11 Botryosphaeriaceae species, namely D. allocellula, Do. brevicollis, Do. dulcispinae, Do. viticola, L. crassispora, L. exigua, L. gonubiensis, L. mahajangana, N. parvum, Oblongocollomyces sp. 1 and Oblongocollomyces sp. 2 on three tree species of Anacardiaceae in the north-eastern parts of South Africa. The majority of these species (10) occurred on trees in undisturbed (isolated and/or protected) ecosystems, compared to only three species in disturbed (agriculture and forestry) ecosystems. Three species overlapped on both native and non-native species. Some species identified in this study are reported for the first time in South Africa or on specific hosts.

The high species diversity recorded on trees in undisturbed ecosystems reflects conclusions from a previous study that biodiversity in natural ecosystems increases fungal diversity compared to ecosystems frequently disturbed by human activities such as clearcutting, selective cutting and land-use changes [39]. Species such as D. allocellula, Do. brevicollis, Do. dulcispinae, Do. viticola, L. exigua, L. gonubiensis, Oblongocollomyces sp. 1 and Oblongocollomyces sp. 2 were identified on trees in undisturbed ecosystems only. The influence of human activity on Botryosphaeriaceae species composition was previously reported by Pavlic et al. [40]. In that study, N. parvum was predominant on S. cordatum in disturbed stands and absent in undisturbed stands where other Neofusicoccum species dominated. 
Our results indicate that activities between the two ecosystems (including deforestation in disturbed ecosystems, opposed to rich plant diversity in undisturbed ecosystems) influence Botryosphaeriaceae species composition. The absence of $N$. parvum on trees in undisturbed ecosystems despite its known presence in the region suggests that undisturbed ecosystems are more resilient to invasion by some invasive Botryosphaeriaceae. This hypothesis is worth testing, as this would imply a potential influence of conserved areas on the spread of invasive species of Botryosphaeriaceae. At the same time, such areas might serve as a reservoir of new species that might infect agricultural and forestry tree species.

Lasiodiplodia crassispora and L. mahajangana were common on the three tree species in disturbed and undisturbed ecosystems. Organisms with a broad niche are often prominent colonizers of disturbed environments and are also successful invaders in new regions $[40,41]$. The presence of $L$. crassispora and L. mahajangana in both ecosystems was not surprising from the perspective that Lasiodiplodia species occurs predominantly in tropical and subtropical regions, such as those sampled in this study [8,13,31]. Furthermore, the two species have been reported in the region before and on tree species of Anacardiaceae [13]. Lasiodiplodia crassispora has been reported on P. angolensis in Mpumalanga [42] and S. birrea in Limpopo and Mpumalanga [13], while L. mahajangana is known to occur on Adansonia digitata, E. ingens and S. birrea in Limpopo and Mpumalanga provinces $[8,13,31]$.

Neofusicoccum parvum was the only species unique to trees in disturbed, agricultural ecosystems. Neofusicoccum paroum was also the dominant species overlapping between $S$. birrea (native) and $M$. indica (non-native) trees in disturbed ecosystems. These results confirm the ease with which this important global pathogen spreads between native and non-native hosts in human-disturbed ecosystems $[12,13,40]$. The abundance and distribution of Neofusicoccum species, and N. parvum in particular, on Syzygium cordatum, has been linked to environmental disturbance and host composition through human activities [40]. Our results provide further support for this hypothesis.

Our study is not the first to investigate species overlap of Botryosphaeriaceae on native and non-native Anacardiaceae in South Africa. Mehl et al. [13] also reported an overlap of $N$. paroum on S. birrea and M. indica in the Hoedspruit area, Mpumalanga Province. The absence of $N$. parvum on $S$. birrea trees in undisturbed areas suggests that the fungus is not indigenous to native hosts, but it is spreading from a non-native ( $M$. indica) to a native (S. birrea) host in disturbed ecosystems, rather than vice versa.

This study represents the first report of L. exigua in South Africa. Lasiodiplodia exigua was described from Retama raetam in Tunisia and Pistacia vera in the United States [43]. The fungus has also been reported to cause canker, dieback, discolouration and streaks on grapevine wood in Turkey and Mexico [44,45]. In the present study, L. exigua was isolated from S. birrea at Mapungubwe National Park. It is curious that this species was identified on a native host in an isolated low disturbance site only, even though it is known from other hosts globally. This demonstrates the ability of this fungus to spread between continents and hosts. Our results indicate that other species that are thought to not occur in the country might exist on unsampled hosts in conserved areas.

Dothiorella brevicollis, Do. dulcispinae, Do. viticola, Oblongocollomyces sp. 1 and Oblongocollomyces sp. 2 on S. birrea, and L. crassispora on M. indica are first reports on these hosts, albeit that these hosts were sampled before for the Botryosphaeriaceae in South Africa. Dothiorella brevicollis and Do. dulcispinae appear to have a narrow host range and limited distribution in South Africa, while on the other hand, Do. viticola appears to have a much wider host and geographic distribution. Dothiorella brevicollis and Do. dulcispinae were both described from $V$. karroo in South Africa and they have not been reported on any other host elsewhere [46]. Therefore, S. birrea is the second host for the two species. Dothiorella viticola was first described as a saprophyte from declining $V$. vinifera in Spain [47]. In South Africa, the fungus has been reported on Celtis africana, Gymnosporia buxifolia, Prunus persica, Podocarpus henkelii, Senegalia mellifera, V. karroo and V. vinifera [21]. Lasiodiplodia crassispora is known to occur on M. indica in Brazil [48]. On native hosts, L. crassispora has been reported on P. angolensis [42] and S. birrea [13] in Mpumalanga. These species are not necessarily 
new introductions, but their discovery might have been influenced by the more extensive (geographic and host) sampling in this study compared to previous efforts.

The six species, Do. brevicollis, Do. dulcispinae, Do. viticola, L. exigua, Oblongocollomyces sp. 1 and Oblongocollomyces sp. 2 recorded on S. birrea for the first time in this study increases the number of Botryosphaeriaceae species known on this host to 17. Some species known to occur on S. birrea in South Africa were not identified in this study. These include B. fabicerciana, L. iraniensis, N. mediterraneum, N. umdonicola and N. vitifusiforme [13]. Except for N. umdonicola and N. vitifusiforme, the other three species that were not isolated in this study are possibly alien and they were recently identified in South Africa [13]. Timing and location of sampling likely influence these outcomes of species diversity on this host and more Botryosphaeriaceae can be expected in previously unsampled areas.

The three fungal species identified on $M$. indica, namely L. crassispora, L. mahajangana and N. paroum are well-known pathogens of this host worldwide [22,48-50]. These species have been reported to cause mango diseases in countries such as Brazil [48], Egypt [49] and Thailand [22]. Only two of the identified species, L. mahajangana and N. parvum are known to occur on M. indica in South Africa [13,22]. This is the first study to report the presence of L. crassispora on M. indica in South Africa, which increases the number of Botryosphaeriaceae species known to occur on M. indica in South Africa to 11.

To our knowledge, this is the first study to consider the presence of Botryosphaeriaceae on L. schweinfurthii in South Africa. Four species, including D. allocellula, Do. brevicollis, L. crassispora and L. mahajangana were identified on this host in undisturbed ecosystems. Diplodia allocellula has been reported on V. karroo in Gauteng [46] and S. birrea in Mpumalanga [13]. Dothiorella brevicollis has only been reported on V. karroo and was isolated on S. birrea in this study, making L. schweinfurthii a third host for the fungus. Lasiodiplodia mahajangana is known to occur on Adansonia digitata [31], E. ingens [8], M. indica and S. birrea [13] in Limpopo and Mpumalanga, while L. crassispora is known to occur on S. birrea and Pterocarpus angolensis in Mpumalanga and Kwa-Zulu Natal [13,42]. The presence of these fungi on L. schweinfurthii supports the assumption that species of Botryosphaeriaceae occur on virtually all woody tree species that have been sampled and many species remain undiscovered on native hosts in unexplored areas [9].

We isolated four isolates for which sequences could not be identified to species level. These sequences clustered with Oblongocollomyces and Sphaeropsis species confirming that the two genera are closely related. These sequences were phylogenetically close to $O$. variabilis but formed separate sub-clades indicating that they represent two species in the genus Oblongocollomyces. Oblongocollomyces was introduced as a monotypic genus to accommodate O. variabilis [51]. In earlier studies, this species was identified as Sphaeropsis variabilis. Oblongocollomyces differ from Sphaeropsis by forming long conidiomatal necks with conidia that can be up to 3-septate [51]. Oblongocollomyces variabilis is the only species in the genus thus far and we refer to the two undescribed species as Oblongocollomyces sp. 1 and Oblongocollomyces sp. 2. The four isolates were obtained from S. birrea trees in Mapungubwe National Park. Our findings mirror that of Jami et al. [21] that reported 52 species of Botryosphaeriales on 32 native hosts in South Africa, of which 27 species were described as new taxa on native hosts in previously unsampled areas in the region [21]. It is thus not surprising to find these potential new species from a native host (S. birrea) in an area (Mapungubwe) that has never been sampled.

Results obtained from analyses of data on tree health assessment show that dieback is common on tree species of Anacardiaceae in the north-eastern parts of the Limpopo and Mpumalanga provinces. Various species of Botryosphaeriaceae have been reported to cause dieback on various trees globally $[8,48,52]$, but none of the species identified in this study could be consistently linked to these symptoms. This study will, however, lay a foundation for future studies to investigate Botryosphaeriaceae species associated with dieback on these trees. 


\section{Conclusions}

Members of Botryosphaeriaceae are diverse on native and non-native Anacardiaceae in disturbed and undisturbed ecosystems. It is evident from this study that land use and disturbance through human activities influence species diversity and distribution of Botryosphaeriaceae. The higher species diversity of Botryosphaeriaceae and the discovery of potential new species in undisturbed ecosystems emphasise the need to consider different habitats and hosts that may influence patterns of diversity and distribution of these fungi. Our results indicate the ease with which invasive pathogens such as N. parvum introduced with non-native hosts can spread and infect native hosts once they are established in the region.

Supplementary Materials: The following are available online at https://www.mdpi.com/article/10 $.3390 /$ f13020341/s1, Figure S1: Genealogical concordance phylogenetic species recognition (GCPSR) based on analyses of the ITS, tef- $1 \alpha, \beta-t u b$ and $r p b 2$ sequence data. Bootstrap values above $70 \%$ and PP values above 0.95 are shown at the nodes. Isolates in bold were obtained in this study. The trees are rooted to isolates of Melanops tulasnei (CBS116805, CBS116806).

Author Contributions: E.R. conducted laboratory work, analyzed the data, and drafted the manuscript. E.K., M.P.A.C. and B.S. conceived the study, assisted with the analyses, contributed to and assisted in writing the manuscript. All authors have read and agreed to the published version of the manuscript.

Funding: This research was funded by the Department of Science and Innovation (DSI)-National Research Foundation (NRF) through the Centre of Excellence in Plant Health Biotechnology (CPHB), grant number 40945 .

Acknowledgments: We thank the Department of Science and Innovation (DSI)-National Research Foundation (NRF), Centre of Excellence in Plant Health Biotechnology (CPHB), the University of Venda and the University of Pretoria, South Africa, for financial support.

Conflicts of Interest: The authors declare no conflict of interest.

\section{References}

1. Slippers, B.; Wingfield, M.J. Botryosphaeriaceae as endophytes and latent pathogens of woody plants: Diversity, ecology and impact. Fungal Biol. Rev. 2007, 21, 90-106. [CrossRef]

2. Van Niekerk, J.M.; Crous, P.W.; Groenewald, J.Z.; Fourie, P.H.; Halleen, F. DNA phylogeny, morphology and pathogenicity of Botryosphaeria species on grapevines. Mycologia 2004, 96, 781-798. [CrossRef]

3. Damm, U.; Crous, P.W.; Fourie, P.H. Botryosphaeriaceae as potential pathogens of Prunus in South Africa, with descriptions of Diplodia africana and Lasiodiplodia plurivora sp. nov. Mycologia 2007, 99, 664-680. [CrossRef]

4. Slippers, B.; Smith, W.A.; Crous, P.W.; Coutinho, T.A.; Wingfield, B.D.; Wingfield, M.J. Taxonomy, phylogeny and identification of Botryosphaeriaceae associated with pome and stone fruit trees in South Africa and other regions of the world. Plant Pathol. 2007, 56, 128-139. [CrossRef]

5. Smith, H.; Wingfield, M.J.; Crous, P.W.; Coutinho, T.A. Sphaeropsis sapinea and Botryosphaeria dothidea endophytic in Pinus species and Eucalyptus species in South Africa. S. Afr. J. Bot. 1996, 62, 86-88. [CrossRef]

6. Slippers, B.; Burgess, T.; Pavlic, D.; Ahumada, R.; Maleme, H.; Mohali, S.; Rodas, C.; Wingfield, M.J. A diverse assemblage of Botryosphaeriaceae infect Eucalyptus in native and non-native environments. South. For. 2009, 71, 101-110. [CrossRef]

7. Pavlic, D.; Slippers, B.; Coutinho, T.A.; Wingfield, M.J. Botryosphaeriaceae occurring on native Syzygium cordatum in South Africa and their potential threat to Eucalyptus. Plant Pathol. 2007, 56, 624-636. [CrossRef]

8. Van der Linde, J.A.; Six, D.L.; Wingfield, M.J.; Roux, J. Lasiodiplodia species associated with dying Euphorbia ingens in South Africa. South. For. 2011, 73, 165-173. [CrossRef]

9. Jami, F.; Slippers, B.; Wingfield, M.J.; Gryzenhout, M. Botryosphaeriaceae species overlap on four unrelated, native South African hosts. Fungal Biol. 2014, 118, 168-179. [CrossRef]

10. Mehl, J.W.M.; Slippers, B.; Roux, J.; Wingfield, M.J. Cankers and other diseases caused by the Botryosphaeriaceae. In Infectious Forest Diseases; Gonthier, P., Nicolotti, G., Eds.; CAB International: Boston, MN, USA, 2013; pp. 298-317.

11. Burgess, T.I.; Tan, Y.P.; Garnas, J.; Edwards, J.; Scarlett, K.A.; Lucas, A.; Shuttleworth, L.A.; Daniel, R.; Dann, E.K.; Parkinson, L.E.; et al. Current status of the Botryosphaeriaceae in Australia. Australas. Plant Pathol. 2018, 48, 35-44. [CrossRef]

12. Pillay, K.; Slippers, B.; Wingfield, M.J.; Gryzenhout, M. Diversity and distribution of co-infecting Botryosphaeriaceae from Eucalyptus grandis and Syzygium cordatum in South Africa. S. Afr. J. Bot. 2013, 84, 38-43. [CrossRef]

13. Mehl, J.W.M.; Slippers, B.; Roux, J.; Wingfield, M.J. Overlap of latent pathogens in the Botryosphaeriaceae on a native and agricultural host. Fungal Biol. 2017, 121, 405-419. [CrossRef] 
14. Slippers, B.; Fourie, G.; Crous, P.W.; Coutinho, T.A.; Wingfield, B.D.; Carnegie, A.J.; Wingfield, M.J. Speciation and distribution of Botryosphaeria species on native and introduced Eucalyptus trees in Australia and South Africa. Stud. Mycol. 2004, 50, 343-358.

15. Jami, F.; Slippers, B.; Wingfield, M.J.; Gryzenhout, M. Greater Botryosphaeriaceae diversity in healthy than associated diseased Acacia karroo tree tissues. Australas. Plant Pathol. 2013, 42, 421-430. [CrossRef]

16. Bihon, W.; Burgess, T.I.; Slippers, B.; Wingfield, M.J.; Wingfield, B.D. Distribution of Diplodia pinea and its genotypic diversity within asymptomatic Pinus patula trees. Australas. Plant Pathol. 2011, 40, 540-548. [CrossRef]

17. Sakalidis, M.L.; Slippers, B.; Wingfield, B.D.; Hardy, G.E.S.J.; Burgess, T.I. The challenge of understanding the origin, pathways and extent of fungal invasions: Global populations of the Neofusicoccum parvum/N. ribis species complex. Divers. Dist. 2013, 19, 873-883. [CrossRef]

18. Marsberg, A.; Kemler, M.; Jami, F.; Nagel, J.H.; Postma-Smidt, A.; Naidoo, S.; Wingfield, M.J.; Crous, P.W.; Spatafora, J.W.; Hesse, C.N. Botryosphaeria dothidea: A latent pathogen of global importance to woody plant health. Mol. Plant Pathol. 2017, 18, 477-488. [CrossRef]

19. Mehl, J.; Wingfield, M.J.; Roux, J.; Slippers, B. Invasive everywhere? Phylogeographic analysis of the globally distributed tree pathogen Lasiodiplodia theobromae. Forests 2017, 8, 145. [CrossRef]

20. Yan, J.Y.; Xie, Y.; Zhang, W.; Wang, Y.; Liu, J.K.; Hyde, K.D.; Seem, R.C.; Zhang, G.Z.; Wang, Z.Y.; Yao, S.W.; et al. Species of Botryosphaeriaceae involved in grapevine dieback in China. Fungal Divers. 2013, 61, 221-236. [CrossRef]

21. Jami, F.; Wingfield, M.J.; Gryzenhout, M.; Slippers, B. Diversity of tree infecting Botryosphaeriales on native and non-native trees in South Africa and Namibia. Australas. Plant Pathol. 2017, 46, 529-545. [CrossRef]

22. Trakunyingcharoen, T.; Cheewangkoon, R.; To-anun, C.; Crous, P.W.; Van Niekerk, J.M.; Lombard, L. Botryosphaeriaceae associated with diseases of mango (Mangifera indica). Australas. Plant Pathol. 2014, 43, 425-438. [CrossRef]

23. Christenhusz, M.J.M.; Byng, J.W. The number of known plants species in the world and its annual increase. Phytotaxa 2016, 261, 201-221. [CrossRef]

24. Kudi, A.C.; Umoh, J.U.; Eduvie, L.O.; Gefu, J. Screening of some Nigerian medicinal plants for antibacterial activity. J. Ethnopharmacol. 1999, 67, 225-228. [CrossRef]

25. Shackleton, S.E.; Shackleton, C.M.; Cunningham, A.B.; Lombard, C.; Sullivan, C.A.; Netshiluvhi, T.R. Knowledge on Sclerocarya birrea subsp. caffra with emphasis on its importance as a non-timber forest product in South and southern Africa: A summary. Part 1: Taxonomy, ecology and role in rural livelihoods. South. Afr. For. J. 2002, 194, $27-41$.

26. Rayner, R.W. A mycological colour chart. Brit. Mycol Soc. 1970, 1, 1-34.

27. Möller, E.M.; Bahnweg, G.; Sandermann, H.; Geiger, H.H. A simple and efficient protocol for isolation of high molecular weight DNA from filamentous fungi, fruit bodies, and infected plant tissues. Nucleic Acids Res. 1992, 20, 6115-6116. [CrossRef]

28. White, T.J.; Bruns, T.; Lee, S.; Taylor, J. Amplification and direct sequencing of fungal ribosomal RNA genes for phylogenetics. In PCR Protocols: A Guide to Methods and Applications; Innis, M.A., Gelfand, D.H., Sninsky, J.J., White, T.J., Eds.; Academic Press: San Diego, CA, USA, 1990; pp. 315-322.

29. Carbone, I.; Kohn, L.M. A method for designing primer sets for speciation studies in filamentous ascomycetes. Mycologia 1999, 91, 553-556. [CrossRef]

30. Glass, N.L.; Donaldson, G.C. Development of primer sets designed for use with the PCR to amplify conserved genes from filamentous ascomycetes. Appl. Environ. Microbiol. 1995, 61, 1323-1330. [CrossRef]

31. Cruywagen, E.M.; Slippers, B.; Roux, J.; Wingfield, M.J. Phylogenetic Species Recognition and hybridisation in Lasiodiplodia: A case study on species from baobabs. Fungal Biol. 2017, 121, 420-436. [CrossRef]

32. Sakalidis, M.L.; Hardy, G.E.S.J.; Burgess, T.i. Use of the Genealogical Sorting Index (GSI) to delineate species boundaries in the Neofusicoccum parvum-Neofusicoccum ribis species complex. Mol. Phylogenet. Evol. 2011, 60, 333-344. [CrossRef]

33. Katoh, K.; Rozewicki, J.; Yamada, K.D. MAFFT online service: Multiple sequence alignment, interactive sequence choice and visualization. Briefings. Bioinf. 2017, 20, 1160-1166. [CrossRef] [PubMed]

34. Posada, D. JModelTest: Phylogenetic model averaging. Mol. Biol. Evol. 2008, 25, 1253-1256. [CrossRef]

35. Stamatakis, A. RAxML version 8: A tool for phylogenetic analysis and post-analysis of large phylogenies. Bioinformatics 2014, 30, 1312-1313. [CrossRef] [PubMed]

36. Ronquist, F.; Teslenko, M.; van der Mark, P.; Ayres, D.L.; Darling, A.; Hohna, S.; Larget, B.; Liu, L.; Suchard, M.A.; Huelsenbeck, J.P. MrBayes 3.2: Efficient Bayesian phylogenetic inference and model choice across a large model space. Syst. Biol. 2012, 61, 539-542. [CrossRef]

37. Rodríguez-Gálvez, E.; Guerrero, P.; Barradas, C.; Crous, P.W.; Alves, A. Phylogeny and pathogenicity of Lasiodiplodia species associated with dieback of mango in Peru. Fungal Biol. 2017, 121, 452-465. [CrossRef]

38. Zhang, W.; Groenewald, J.Z.; Lombard, L.; Schumaker, R.K.; Phillips, A.J.L.; Crous, P.W. Evaluating species of Botryosphaeriales. Persoonia 2021, 46, 63-115. [CrossRef]

39. Opik, M.; Moora, M.; Liira, J.; Zobel, M. Composition of root-colonising arbuscular mycorrhizal fungal communities in different ecosystems around the globe. J. Ecol. 2006, 94, 778-790. [CrossRef]

40. Pavlic, D.; Wingfield, M.J.; Boissin, E.; Slippers, B. The distribution of genetic diversity in the Neofusicoccum parvum/N. ribis complex suggests structure correlated with level of disturbance. Fungal Ecol. 2015, 13, 93-102. [CrossRef]

41. Lee, C.E.; Gelembiuk, G.W. Evolutionary origins of invasive populations. Evol. Appl. 2008, 1, 427-448. [CrossRef] 
42. Mehl, J.W.M.; Slippers, B.; Roux, J.; Wingfield, M.J. Botryosphaeriaceae associated with Pterocarpus angolensis (kiaat) in South Africa. Mycologia 2011, 103, 534-553. [CrossRef]

43. Linaldeddu, B.T.; Deidda, A.; Scanu, B.; Franceschini, A.; Serra, S.; Berraf-Tebbal, A.; Boutiti, M.Z.; Jamâa, M.B.; Phillips, A.J Diversity of Botryosphaeriaceae species associated with grapevine and other woody hosts in Italy, Algeria and Tunisia, with descriptions of Lasiodiplodia exigua and Lasiodiplodia Mediterranea sp. nov. Fungal Divers. 2015, 71, 201-214. [CrossRef]

44. Akgül, D.S.; Savaş, N.G.; Özarslandan, M. First report of wood canker caused by Lasiodiplodia exigua and Neoscytalidium novaehollandiae on grapevine in Turkey. Plant Dis. 2019, 103, 1036. [CrossRef]

45. Montoya, E.A.; Paolinelli, M.; Rolshausen, P.E.; Valenzuela-Solano, C.; Martinez, R. Characterization of Lasiodiplodia species associated with grapevines in Mexico. Phytopathol. Mediterr. 2021, 60, 237-251. [CrossRef]

46. Jami, F.; Slippers, B.; Wingfield, M.J.; Gryzenhout, M. Five new species of the Botryosphaeriaceae from Acacia karroo in South Africa. Cryptogam. Mycol. 2012, 33, 245-266. [CrossRef]

47. Luque, J.; Martos, S.; Phillips, A.J.L. Botryosphaeria viticola sp. nov. on grapevines: A new species with a Dothiorella anamorph. Mycologia 2005, 97, 1111-1121. [CrossRef] [PubMed]

48. Marques, M.W.; Lima, N.B.; De Morais, A.M.; Barbosa, M.A.G.; Souza, B.O.; Michereff, S.J.; Phillips, A.J.L.; Câmara, M.P.S. Species of Lasiodiplodia associated with mango in Brazil. Fungal Divers. 2013, 61, 181-193. [CrossRef]

49. Ismail, A.M.; Cirvilleri, G.; Polizzi, G.; Crous, P.W.; Groenewald, J.Z.; Lombard, L. Lasiodiplodia species associated with dieback disease of mango (Mangifera indica) in Egypt. Australas. Plant Pathol. 2012, 41, 649-660. [CrossRef]

50. Ni, H.F.; Yang, H.R.; Chen, R.S.; Hung, T.H.; Liou, R.F. A nested multiplex PCR for species-specific identification and detection of Botryosphaeriaceae species on mango. Eur. J. Plant Pathol. 2012, 133, 819-828. [CrossRef]

51. Yang, T.; Groenewald, J.Z.; Cheewangkoon, R.; Jami, F.; Abdollahzadeh, J.; Lombard, L.; Crous, P.W. Families, genera and species of Botryosphaeriales. Fungal Biol. 2016, 121, 322-346. [CrossRef]

52. Iturritxa, E.; Slippers, B.; Mesanza, N.; Wingfield, M.J. First report of Neofusicoccum parvum causing canker and die-back of Eucalyptus in Spain. Australas. Plant Dis. 2011, 6, 57-59. [CrossRef] 